\title{
A Review on Pineapple Leaves Fibre and Its Composites
}

\author{
M. Asim, ${ }^{1}$ Khalina Abdan,, ${ }^{1,2}$ M. Jawaid, ${ }^{1}$ M. Nasir, ${ }^{3}$ Zahra Dashtizadeh, ${ }^{1}$ \\ M. R. Ishak, ${ }^{4}$ and M. Enamul Hoque ${ }^{5}$ \\ ${ }^{1}$ Laboratory of Biocomposite Technology, Institute of Tropical Forestry and Forest Products (INTROP), Universiti Putra Malaysia, \\ 43400 Serdang, Selangor, Malaysia \\ ${ }^{2}$ Department of Biological and Agricultural Engineering, Faculty of Engineering, Universiti Putra Malaysia, \\ 43400 Serdang, Selangor, Malaysia \\ ${ }^{3}$ School of Industrial Technology, Universiti Sains Malaysia, 11800 Penang, Malaysia \\ ${ }^{4}$ Department of Aerospace Engineering, Universiti Putra Malaysia, 43400 Serdang, Selangor, Malaysia \\ ${ }^{5}$ Department of Mechanical, Materials \& Manufacturing Engineering, University of Nottingham Malaysia Campus, \\ Jalan Broga, 43500 Semenyih, Selangor, Malaysia
}

Correspondence should be addressed to M. Jawaid; jawaid_md@yahoo.co.in

Received 6 February 2015; Accepted 20 April 2015

Academic Editor: Yulin Deng

Copyright (c) 2015 M. Asim et al. This is an open access article distributed under the Creative Commons Attribution License, which permits unrestricted use, distribution, and reproduction in any medium, provided the original work is properly cited.

\begin{abstract}
Natural fibre based composites are under intensive study due to their ecofriendly nature and peculiar properties. The advantage of natural fibres is their continuous supply, easy and safe handling, and biodegradable nature. Although natural fibres exhibit admirable physical and mechanical properties, it varies with the plant source, species, geography, and so forth. Pineapple leave fibre (PALF) is one of the abundantly available wastes materials of Malaysia and has not been studied yet as it is required. A detailed study of chemical, physical, and mechanical properties will bring out logical and reasonable utilization of PALF for various applications. From the socioeconomic prospective, PALF can be a new source of raw material to the industries and can be potential replacement of the expensive and nonrenewable synthetic fibre. However, few studies on PALF have been done describing the interfacial adhesion between fibres and reinforcement compatibility of fibre but a detailed study on PALF properties is not available. In this review, author covered the basic information of PALF and compared the chemical, physical, and mechanical properties with other natural fibres. Furthermore, it summarizes the recent work reported on physical, mechanical, and thermal properties of PALF reinforced polymer composites with its potential applications.
\end{abstract}

\section{Introduction}

Industries are widely using plant fibres for numerous applications from many resources. In the middle of 20th century, synthetic fibres rose up drastically, and natural fibres industries collapse its market shares. For promoting natural fibre and material, year 2009 is considered as international year of natural fibre (IYNF), which is highly supportive to famers, agriculture, environment, and market demands. Composite market of United States has been recorded 2.72.8 billion pounds from 2006 to 2007. On the basis of compound annual growth rate of $3.3 \%$, it is estimated to cross over 3.3 billion pounds [1]. In 2009, Thailand produces 1.894 million tonnes, the Philippines produced 2.198 million tonnes, and Brazil produced only 1.43 million tonnes. In 2001 the production of Costa Rica, Cote d'lvoire, and Philippines were 322,000 tonnes, 188,000 tonnes, and 135000 tonnes, respectively [2]. The most important property of natural fibre is biodegradability and noncarcinogenic which bring it back into fashion, with an advantage of being cost-effective. The versatile nature of it makes it suitable for automobiles, railway coach, building construction, partition wall cabinets, or furniture for machinery uses and packaging. Natural fibres are important agricultural biomass contributing to Malaysian economy. The huge and wide range availability of natural fibre can reduce the pressure on forest and agriculture. The usage of diverse raw materials will help to keep a ecological balance in nature. Generally agriculture materials and forest product produce $30-40 \%$ waste materials, which can also be used in value added processing. The low density 
natural fibres can also be utilised as per the aim of utility. For example, a grass fibre can be a good alternative for low load bearing products [3]. It has cumulative advantage of light weight (low density), cheaper source, low wages, being noncarcinogenic, and biodegradability [4-6]. Scientists and engineers are having great interest to find out new sources of raw materials that possess comparable physical and mechanical properties to synthetic fibres. Various other parameters to be considered while selecting raw materials are being cheap, being ecofriendly [7], absence of health hazards, high degree of flexibility [8], lower plant's age, easy collection, and regional availability which directly influence the suitability of natural fibres $[9,10]$. Above all the natural fibres are renewable resource, thus providing a better solution of sustainable supply, like it has low cost, low density, least processing expenditure, no health hazards, and better mechanical and physical properties [11-16]. The main drawback of natural fibre is moisture absorption, so it is bound to change its surface property by using chemicals [17]. Synthetic fibre reinforced polymers were costly and have an impact on environment [18]. There are many plant fibres available which has potential to be applied in industries as raw materials such as pineapple, kenaf, coir, abaca, sisal, cotton, jute, bamboo, banana, Palmyra, talipot, hemp, and flex [16-21]. Pineapple leaf fibre (PALF) is one of the waste materials in agriculture sector, which is widely grown in Malaysia as well as Asia. After banana and citrus, pineapple (Ananas comosus) is one of the most essential tropical fruits in the world [22]. Commercially pineapple fruits are very important and leaves are considered as waste materials of fruit which is being used for producing natural fibres. The chemical composition of PALF constitute holocellulose (70$82 \%)$, lignin (5-12\%), and ash (1.1\%). Pineapple (PALF) has tremendous mechanical properties and can be applied in making of reinforced polymer composites [23, 24], low density polyethylene (LDPE) composites, and biodegradable plastic composites. Physical and mechanical properties of composites like viscoelastic behaviour processing, tensile strength, flexural strength, and impact are dependent on length of fibre, matrix ratio, and fibre arrangement $[25,26]$. The main drawbacks PALF is hydrophilic nature; it does not make good bonding with hydrophobic matrix, particularly at high temperatures [27]. Interfacial quality between PALF and polymer could be enhanced by using chemical treatments like dewaxing, treatment with $\mathrm{NaOH}$, cyanoethylation, and grafting of acrylonitrile monomer onto dewaxed PALF [24]. Moreover, the surface modification by chemicals like sodium hydroxide $(\mathrm{NaOH}), 2,4$-dinitrochlorobenzene, benzoyl peroxide (BPO), and $\mathrm{BPO} /$ acetylation can minimize water absorption and improves the mechanical properties [28]. The moisture absorption of chemically modified PALFreinforced LDPE composites shows considerably less moisture content [29]. Bonding agent resorcinol (reso), hexamethylenetetramine (Hexa), and silica have good affinity for PALF-natural rubber (NR) and exhibits better adhesion [30].

Nowadays, biocomposite reinforced materials are widely accepted in place of traditional materials in high strength and several light weight applications. Such composite materials exhibit good strength by weight ratio, high tensile and flexural strength, high creep resistance, and high compactness. Natural fibres reinforced into bioplastics are a good example of green composites, which is easily degradable by bacteria and enzyme [31]. The major problem of natural fibres as a reinforced material is improper contact of adherent surface and polymer matrix with a bad interaction load transformation from matrix to fibre [32]. Thus, to enhance the adhesion property of fibres, it needs surface modification by using appropriate chemicals. These modification methods can be alkaline treatment [33] grafting with malic anhydride copolymer [34] and using saline coupling agent [35].

\section{Natural Fibre}

It is believed that source of petroleum based products are limited and uncertain. So an alternative with cheap sustainable and easily available raw material is required. The countries growing plant and fruit are not for only agricultural purpose but also to generate raw materials for industries. Most of the developing countries trade lignocellulosic fibres for improving economic condition of poor farmers as much as country support. Recently polymer composites containing cellulosic fibres are under focus in literature as well as industries. Table 1 shows the annual natural fibre production from various sources. Near about 30 million tonnes of natural fibres are produced every year and used as component of many manufacturing processes like clothing, packaging, paper making, automobiles, building materials, and sports equipment [1]. Natural fibres composites are eye-catching to industry because of its density and ecofriendly nature over traditional composites [36]. Other than plant fibres, various animal fibres also have different types such as products from the wool, silk, feathers, avian fibre, and animals hairs which are prime resource. Fruit fibres are taken from fruits like coconut (coir) fibre. Stalk fibres are collected from husk and straw of crops like wheat, rice, barley, and so forth. Tree wood can also be used as fibre. Natural fibres have been used for a long time in many developing countries as cement materials [37].

These fibres are thread-like structure of various sizes; it can be used in rope or threads making; now it is major component of biocomposite materials like boards, paper, and many structures [17].

The performance of natural fibre varies with part of the plant that is used for fibre extraction, age of plant, fibre extraction process, and many more factors [38]. It can be extracted from the bast stem, leaf, and seeds from the plants in a bundle form; therefore it is also called fibre bundles; extraction method of fibres is similar in both bast stem and leaf, while seed fibres have many methods like cotton lint extracted from ginning process. The strip fibre bundle is extracted from stem and leaf; decorticator technique is recommended. Retting technique prefers to use chemicals and biological treatment for removing fibres from stem; retting is basically two types: dry retting and water retting [39]. Dew retting is most popular in Europe, but its quality is not good as much as water retting. Water retting technique is being used in Asian countries [40]. 
TABLE 1: Annual production of natural fibres and sources [41-43].

\begin{tabular}{lcc}
\hline Fibre source & World production $\left(10^{3}\right.$ Tons $)$ & Origin \\
\hline Abaca & 70 & Stem \\
Bamboo & 10,000 & Stem \\
Banana & 200 & Fruit \\
Broom & Abundant & Stem \\
Coir & 100 & Stem \\
Cotton Lint & 18,500 & Stem \\
Elephant grass & Abundant & Stem \\
Flax & 810 & Stem \\
Hemp & 215 & Stem \\
Jute & 2,500 & Stem \\
Kenaf & 770 & Stem \\
Linseed & Abundant & Fruit \\
Pineapple & Abundant & Leaf \\
Caroa & - & Leaf \\
Nettles & Abundant & Stem \\
Oil palm fruit & Abundant & Fruit \\
Palm rah & Abundant & Stem \\
Ramie & 100 & Stem \\
Roselle & 250 & Stem \\
Rice husk & 75,000 & Fruit/grain \\
Rice straw & - & Stem \\
Sisal & Abundant & Stem \\
Sun hemp & Abundant & Stem \\
Wheat straw & 380 & Stem \\
Wood & Stem \\
Sugarcane bagasse & Stem \\
Cantala & Leaf \\
China jute & Stem \\
\hline & &
\end{tabular}

Natural fibres have systematic internal cell wall structure which is divided into three major structural parts [80]. The microfibril angle and arrangement inside the cell wall decide the properties of fibres [81]. Cell wall mainly consists of two cell walls, primary cell wall (S1) and secondary cell wall (S2). Primary cell wall propagates at the time of growth of plant. Secondary cell wall is made up by three layers and each layer carries long chain of microfibril [82]. Amount of cellulose increases from S1 to S2 steadily and hemicelluloses content remains the same in each layer but lignin content shows reciprocal trend to cellulose. Hemicelluloses molecules are netlike structure and make bond with cellulosic fibrils. Cellulosehemicelluloses make network together and lignin and pectin provide an adhesive quality. These adhesive properties are responsible for strength and rigidity of cellulosic fibres. Secondary layer (S2) decides the physical and mechanical strength of fibres. Normally high level of cellulose content and lower microfibrillar angle provide better strength properties $[55,83]$. In general synthetic fibres show better mechanical and physical properties compared to the natural fibre whereas the specific modulus and elongation at break are better in natural fibres than the synthetic fibres, which is considered as an important factor in polymer engineering composites [49].
The major chemical composition of fibres like coir, banana, pineapple leaf, sisal, Palmyra, sunhemp, and so forth are cellulose and lignin discussed in Table 2. Natural fibres are constitutes of cellulose and lignin; these celluloses consist of many fibrils along the length which is, associated with hydrogen bond to provide strength and flexibility [84].

The fibre selection depends on the length, strength, and purpose of usage. Table 3 discusses the physical and mechanical properties of various cellulosic fibres, with their respective density, microfibril angle, Young's modulus, and fibre elongation of fibres that determine the overall properties of the fibres [43]. Cell dimension of lignocellulosic fibres depends on the species, maturity, and location of the plant and also on the fibre extraction conditions [1].

It is believed that the resins produced from petroleum products are not fully biodegradable. However the composite produced from such matrix resin with reinforced natural fibres is considered biodegradable. Matrix material of thermosets and thermoplastics should be compatible for the natural composites [85-87]. The thermoset composite formulation is more complex than thermoplastic. It depends on many parameters like flowing agents, resin, curing agents, catalysts, and hardeners. Such composites need to be chemically cured by using perfect cross-linkage with all direction setup structure. The cross-linked structures are tough, creep resistant, and highly solvent resistant. Fibre loading can enhance the property up to $80 \%$ because of alignment of fibres. Thermoplastics provide more advantage over thermoset polymers. Thermoplastics matrix composite is having low processing cost, design flexibility, and ease of moulding complexity. It is very simple method for processing of composites such as extrusion or injection moulding methods. In thermoplastics, most of the work has been done with polyethylene, polypropylene, polystyrene, and polyvinyl chloride (PVC) polymers. These polymers require temperature below $200^{\circ} \mathrm{C}$ temperature which is suitable for natural fibres and avoid thermal degradation. In thermoplastic composites, fibres distribution plays an important role to achieve quality products. Since natural fibre varies its properties, such as length density, it is very difficult to control the mass production. Natural fibres are highly affected by its growing environment such as composition of soil, temperature, humidity, and frost. Plantation and harvesting methods can also cause variation in density [88]. Natural fibres are tough, elastic and demonstrate good mechanical strength. The composite from natural fibres is introduced for commercial purpose and becomes a good alternative of glass reinforced composites in many uses. A comparison of various parameters between natural fibres and glass fibres is described in Table 4.

Although synthetic composites like glass fibres have high density with significantly high cost, natural fibre (flax fibres) exhibits fairly good density of $1.5 \mathrm{~g} / \mathrm{cm}^{3}$ and cost between $\$ 0.22$ and $\$ 1.10 / \mathrm{kg}[89]$. In other words, the cost of glass fibres is nearly about 1200-1800 US\$/tonnes and density is around $2500 \mathrm{~kg} / \mathrm{m}^{3}$ while natural fibres cost lies between 200 and $1000 \mathrm{US} \$ /$ tonnes and density varies from 1200 to $1500 \mathrm{~kg} / \mathrm{m}^{3}$ [90]. 
TABLE 2: Chemical composition of natural fibres [41, 44].

\begin{tabular}{|c|c|c|c|c|c|c|c|c|}
\hline Type of fibre & Cellulose & Lignin & $\begin{array}{c}\text { Hemicellulose } \\
\text { (\%) }\end{array}$ & Pectin (\%) & Ash (\%) & $\begin{array}{c}\text { Moisture } \\
\text { content (\%) }\end{array}$ & Waxes & $\begin{array}{l}\text { Microfibrillar } \\
\text { angle (deg) }\end{array}$ \\
\hline Fibre flax & 71 & 2.2 & $18.6-20.6$ & 2.3 & - & $8-12$ & 1.7 & $5-10$ \\
\hline Seed flax & $43-47$ & $21-23$ & $24-26$ & - & 5 & - & - & - \\
\hline Kenaf & $31-57$ & $15-19$ & $21.5-23$ & - & $2-5$ & - & - & - \\
\hline Jute & $45-71.5$ & $12-26$ & $13.6-21$ & 0.2 & $0.5-2$ & $12.5-13.7$ & 0.5 & 8.0 \\
\hline Hemp & $57-77$ & $3.7-13$ & $14-22.4$ & 0.9 & 0.8 & $6.2-12$ & 0.8 & 2.62 \\
\hline Ramie & $68.6-91$ & $0.6-0.7$ & $5-16.7$ & 1.9 & - & $7.5-17$ & 0.3 & 7.5 \\
\hline Kenaf & $37-49$ & $15-21$ & $18-24$ & - & $2-4$ & - & - & - \\
\hline Jute & $41-48$ & $21-24$ & $18-22$ & - & 0.8 & $12.5-13.7$ & 0.5 & 8 \\
\hline Abaca & $56-63$ & $7-9$ & $15-17$ & - & 3 & $5-10$ & - & - \\
\hline Sisal & $47-78$ & $7-11$ & $10-24$ & 10 & $0.6-1$ & $10-22$ & 2 & $10-22$ \\
\hline Henequen & 77.6 & 13.1 & $4-8$ & - & - & - & - & - \\
\hline
\end{tabular}

TABLE 3: Mechanical properties of natural fibre $[44,45]$.

\begin{tabular}{lccccc}
\hline Fibre & Density $\left(\mathrm{g} / \mathrm{cm}^{3}\right)$ & Elongation $(\%)$ & Tensile strength $(\mathrm{MPa})$ & Moisture absorption & Young's modulus $(\mathrm{GPa})$ \\
\hline Cotton & $1.5-1.6$ & $3.0-10.0$ & $287-597$ & $8-25$ & 12 \\
Jute & $1.3-1.46$ & $1.5-1.8$ & $393-800$ & 7 & $10-30$ \\
Flax & $1.4-1.5$ & $1.2-3.2$ & $345-1500$ & 8 & $27.6-80$ \\
Hemp & 1.48 & 1.6 & $550-900$ & $12-17$ & 70 \\
Ramie & 1.5 & $2.0-3.8$ & $220-938$ & 11 & $44-128$ \\
Sisal & $1.33-1.5$ & $2.0-14$ & $400-700$ & 10 & $9.0-38.0$ \\
Coir & 1.2 & $15.0-30.0$ & $175-220$ & - & $4.0-6.0$ \\
Softwood kraft & 1.5 & - & 1000 & - & 40.0 \\
E-glass & 2.5 & $2.5-3.0$ & $2000-3500$ & - & 70.0 \\
S-glass & 2.5 & 2.8 & 4570 & - & 86.0 \\
Aramide (normal) & 1.4 & $3.3-3.7$ & $3000-3150$ & - & $63.0-67.0$ \\
Carbon (standard) & 1.4 & $1.4-1.8$ & 4000 & - & $230.0-40.0$ \\
\hline
\end{tabular}

TABLE 4: Comparison between glass fibre and natural fibres [45].

\begin{tabular}{lcc}
\hline Properties & Natural fibre & Glass fibre \\
\hline Density & Low & Double \\
Cost & Low & High \\
Renewability & Yes & No \\
Recyclability & Yes & No \\
Energy consumption & Low & High \\
Distribution & Wide & Wide \\
$\mathrm{CO}_{2}$ neutral & Yes & No \\
Abrasion to the machine & No & Yes \\
Health risk when inhaled & No & Yes \\
Disposal & Biodegradable & Nonbiodegradable
\end{tabular}

\section{Pineapple Plant}

Pineapple is perennial herbaceous plant with $1-2 \mathrm{~m}$ for height and width belongs to family Bromeliaceae [91]. It is chiefly cultivated in coastal and tropical regions, mainly for its fruits purpose. In India, it is cultivated on about 2250000 acres of land [92] and is continuously increasing its production. Figures 1(a) and 1(b) show a pineapple plant in the field; it is a short stem with dark green colour. First sprout of leaf looks decorative; later it converts into $3 \mathrm{ft}$. long, 2 to 3 inch wide sword shaped and numerous spirally arranged fibrous leaves edges as well as curved towards the cross section to maintain the stiffness of the leaf [93].

Each pineapple fruit has equal number of hexagonal sections on outer shell and does not depend on the size or shape. Now Malaysia is one of large producers in Asia as much as Hawaii. It produces a huge amount of waste material, about 384,673 metric tonnes in year 2008 [2]. Productions of Pineapple leaf fibres are plentiful for industrial purpose without any supplementary addition and annually renewable and of easy availability [94]. Pineapple is known as Nanas in Malaysia; basically they use different varieties for different purpose; for commercial purpose they use red pineapple and green pineapple; for edible purpose, they prefer Sarawak pineapple and Morris pineapple. Pineapple fruits contain many major and minor elements. Table 5 shows the percentage of elemental found in pineapple fruit. It is source of bioactive compounds, particularly in proteolytic enzymes. Pineapple is very rich source of bromelain and other cysteine proteases are present in different part of pineapple $[95,96]$. Commercially, bromelain has been used in many food industries, cosmetics, and dietary supplements [46, 97]. 
TABLE 5: Elemental composition of pineapple plant.

\begin{tabular}{lcccccccccc}
\hline $\mathrm{C}$ & $\mathrm{O}$ & $\mathrm{N}$ & $\mathrm{Ca}$ & $\mathrm{P}$ & $\mathrm{Fe}$ & $\mathrm{k}$ & $\mathrm{Mg}$ & $\mathrm{Cu}$ & $\mathrm{O} / \mathrm{C}$ ratio & $\mathrm{Reference}$ \\
\hline 73.13 & 24.17 & 2.70 & 0.00 & - & - & - & - & 0.00 & $0.33 \%$ & {$[46]$} \\
- & - & $6.4-10$ & $2.5-10$ & $0.1-0.18$ & $0.06-0.11$ & 2.89 & 0.33 & $0.002-0.02$ & - & {$[47]$} \\
\hline
\end{tabular}

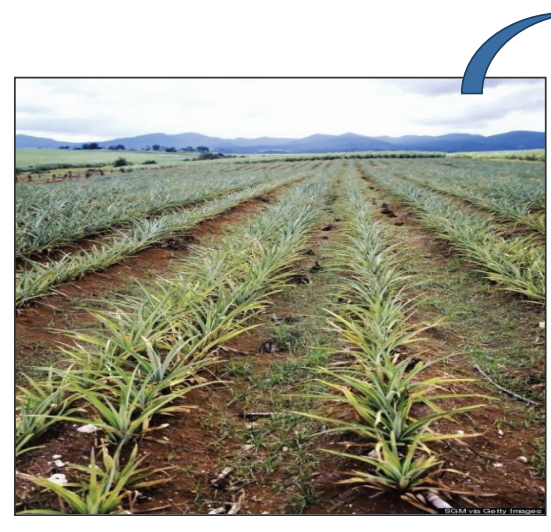

(a) Pineapple field

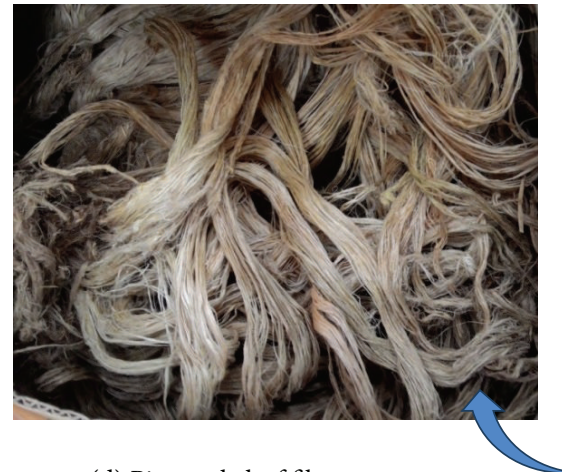

(d) Pineapple leaf fibres



(b) Fruit of pineapple

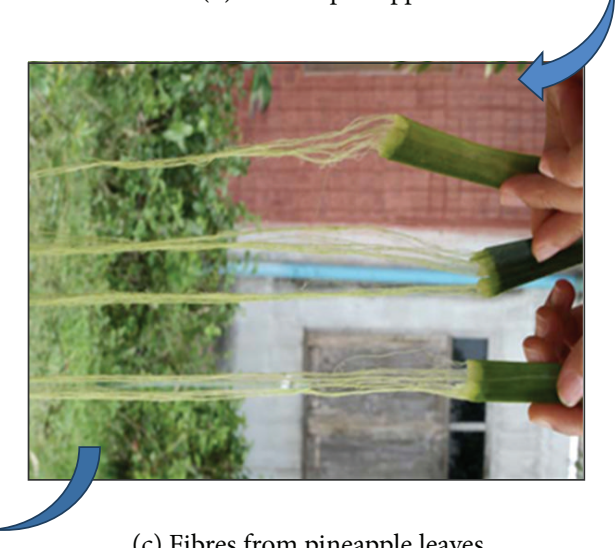

(c) Fibres from pineapple leaves

Figure 1: Production of pineapple leaf fibre, sequential (a) plantation of pineapple, (b) fruit of pineapple, (c) extraction of fibres from pineapple leaves, and (d) Indonesian PALF.

3.1. History. Pineapple is a native plant of America, first seen by Columbus and his companion in November 4, 1493, at an island of West Indies. When the new world was discovered, pineapple has been spread all over South America coastal region as well as in tropical regions. A Spanish government officer, De Oviedo, came to America in 1513; he handed over first written documents of some varieties of pineapple, and he added some Indies varieties also. The plant is called "pineapple" because of its fruit which look like pine cone. The native Tupi word for the fruit was anana, meaning "excellent fruit;" this is the source for words like ananas, common in many languages. The pineapple is an old emblem of welcome and can often be seen in stamped decorations. In 17th century Americans imported pineapple from Caribbean because of its apparently exotic features and rareness; pineapple began to be considered as an icon of wealthy people in America. The Portuguese contributed their important role in introducing the fruit throughout the whole tropical regions and major parts of world like south and east coast of Africa, Madagascar, south India, China, Java, Philippines, and Malaysia [47]. Nowadays, varieties of pineapple plants are available which are used in various applications such as edible, medicinal, and industrial applications. For example, bromelain is an enzyme extracted from its leaves and helps in respiratory ailments. A mixture of pineapple juice and sand is powerful cleaner for boat decks. Dehydrated waste material of pineapple is used as bran feed for cattle, chicken, pigs, and so forth [98].

3.2. Pineapple Leaf Fibre. Every year tonnes of pineapple leaf fibres are being produced, though very small portions are being used in the field of feedstock and energy production. The expansion of biocomposites has amplified industrial usage that would release the possibilities to minimize the wastage of renewable materials. It promotes a non-foodbased market for agricultural industry [99]. It is white in colour, smooth, and glossy as silk, medium length fibre with high tensile strength. It has a softer surface than other natural fibres and it absorbs and maintains a good colour [100]. 
However, PALF has high specific strength and stiffness; it is hydrophilic in nature due to high cellulose content [101103]. Extraction of fibres from pineapple leaf fibre is carried out by mechanical method and retting method, exhibited in Figure $1(\mathrm{c})$. Fresh leaves yield about 2 to $3 \%$ of fibres [104]. Fibrous cell of PALF consists of vascular bundle system in the form of bunches which is obtained after mechanical removal of the entire upper layer after harvesting. PALF is composed of many chemicals constituents. It is multicellular lignocellulosic fibre containing polysaccharides, lignin in major amount, and some miner chemicals like fat, wax, pectin, uronic acid, anhydride, pentosan, colour pigment, inorganic substance, and so forth [105]. Fibre is collection of thin and small multicellular fibres which appears like a thread. These cells are tightly joined with the help of pectin [106]. PALF constitute cellulose (70-82\%) and arrangement of fibres is the same as in cotton $(82.7 \%)[55,107,108]$.

In all the collection, pineapple leaf fibre is more compatible natural fibre resource and constitutes a good chemical composition. PALF has better mechanical strength than the jute when it is used in making of fine yarn $[109,110]$. The cellulosic molecules model of PALF is a three-dimensional structure and parallel to crystalline region of the fibre. Remaining parts of molecular structure are supposed to associate within amorphous regions. Pineapple leaf fibre (PALF) is vital natural fibre, which have high specific strength, rigidity, and flexural and torsional rigidity as much as jute fibres. Considering these exclusive properties of PALF, industries can use it as an outstanding alternative raw material in the prospect of reinforcing composite matrixes [30].

3.3. Extraction of Pineapple Leaf Fibres (PALF). Pineapple natural fibres have excellent mechanical strength but due to lack of knowledge it is still not utilised properly. It can be used in various applications like artificial fibres, as a sound absorber and thermal insulator, and so forth. There are various methods to extract the PALF from leaves of pineapple.

3.3.1. Scrapping Method of Extraction. Scrapping machine is the machine used for scrapping the pineapple leaf fibre [111]. The machine is the combination of three rollers: (a) feed roller, (b) leaf scratching roller, and (c) serrated roller [53]. Feed roller is used for the feeding of leaves into the machine; then leaves go through the second roller that is called scratching roller. It scratches upper layer of leaf and removes the waxy layer. And at last leaves come to the dense attached blade serrated roller, which crushes leaves and makes several breaks for the entry passage for the retting microbes [112].

3.3.2. Retting of Pineapple Leaves. In retting process, small bundles of scratched pineapple leaves are immersed in a water tank which contains substrate : liquor in $1: 20$ ratio, urea $0.5 \%$, or diammonium phosphate (DAP) for fast retting reactions. Materials in water tank are regularly checked by using finger to ensure fibre are loosened and can extract many chemical constituents like pentosans, lignin, fat and wax, ash content, nitrogenous matter, and pectin. After retting process, fibres are segregated mechanically, through washing in pond water. Extracted fibres are dried in hanging place by air. Both ball mill and disc mill can be used to extract PALF from chopped fresh pineapple leaf [113]. The methods not only are simple but also provide higher fibre yield and smaller fibre than the conventional methods. Among the two mechanical grinding methods studied, wet ball milling is much slower but provides PALF with a greater number of elementary fibre [114].

3.4. Chemical Composition. Technical Association of Pulp and Paper Industry (TAPPI) [115] standards reported that the chemical constituents and extractive like holocellulose, $\alpha$-cellulose, lignin, and ash content of PALF were analysed from different source of fibres, age of fibres, and climatic conditions. The procedure to extract the fibres may attribute the factor of various types of chemical composition and cell wall structure [116]. In a transmission electron microscopy, PALF cell wall shows distinct different layers as primary (P), secondary, and tertiary (S1, S2, and S3) layers. The chemical composition of PALF is depicted in Table 6. Pineapple leaf fibres have many chemical constituents like $\alpha$-cellulose, pentosans, lignin, fat and wax, pectin, nitrogenous matter, ash content, degree of polymerization, crystallinity of $\alpha$-cellulose, and antioxidants $[54,117,118]$. PALF has a large quantity of $\alpha$-cellulose (81.27), low quantities of hemicelluloses $(12.31 \%)$, and lignin content (3.46\%) [106]. PALF has higher cellulosic content as compared to other natural fibres like oil palm frond, coir, and banana stem fibres [116]. The higher quantity of cellulose in PALF supports the higher weight of the fruit [119]. The chemicals composition fibre directly affects performance of fibres [120].

3.5. Physical and Mechanical Properties. Reinforced natural fibres composite plays a huge share in biocomposite and material science. PALF has been proved as a good substitute of synthetic fibres, because of its economical and renewable nature. Specific strength of natural fibres supports in enhancing the physical and mechanical strength of polymer matrix without using any additional processing. The superiority of PALFs mechanical properties is related with the high content of alpha-cellulose content and low microfibrillar angle $\left(14^{\circ}\right)$. Due to extraordinary qualities of PALF, it can be used as reinforcing composite matrix [30]. The physicomechanical properties of any natural fibres depend on fibre-matrix adhesion, volume fraction of fibre, aspect ratio, orientation, and stress transfer efficiency at interface [60]. The result of PALF based polymer composites shows excellent stiffness and strength compared to other cellulose based composite materials [73]. Strange characteristics of PALF are noticed; that is, a wet PALF bundle exhibits lower strength by $50 \%$, but when it converts into yarn, its strength increases up to $13 \%$. Table 7 shows the physical and mechanical strength of PALF. The PALF exhibits a modulus range from 34.5 to $82.51 \mathrm{GN} \cdot \mathrm{m}^{-2}$, tensile strength ranges from 413 to $1627 \mathrm{MN} \cdot \mathrm{m}^{-2}$, and an elongation at breakpoint ranges from 0.8 to $1.6 \%$. PALF can sustain abrasiveness [121]. Datta et al. [122] studied many different types of properties and behaviour like morphology of surface structure, tensile 
TABLE 6: Chemicals composition of PALF.

\begin{tabular}{|c|c|c|c|c|c|c|c|c|c|}
\hline $\begin{array}{l}\text { Cellulose } \\
\text { content (\%) }\end{array}$ & $\begin{array}{l}\text { Hemicellulose } \\
(\mathrm{wt} . \%)\end{array}$ & $\begin{array}{l}\text { Lignin } \\
\text { content } \\
(\%)\end{array}$ & $\begin{array}{l}\text { Pectin } \\
\text { (wt.\%) }\end{array}$ & Holocellulose & $\begin{array}{c}\text { Moisture } \\
\text { content } \\
\text { (wt.\%) }\end{array}$ & Extractives & $\begin{array}{l}\text { Ash } \\
(\%)\end{array}$ & Fat \& wax & $\begin{array}{c}\text { PALF } \\
\text { composition } \\
\text { /reference }\end{array}$ \\
\hline 85 & - & 12 & - & - & - & - & - & - & {$[48]$} \\
\hline $70-82$ & - & $5-12$ & - & - & 11.8 & - & - & & [49] \\
\hline $67.1-69.3$ & - & $14.5-15.4$ & - & - & - & - & 1.21 & - & {$[50]$} \\
\hline 68.5 & 18.8 & 6.04 & 1.1 & - & - & - & 0.9 & 3.2 & {$[51]$} \\
\hline 69.5 & - & 4.4 & 1.2 & - & - & - & 2.7 & 4.2 & {$[52]$} \\
\hline 69.5 & - & 4.4 & 1.1 & - & - & - & 0.9 & 3.3 & [53] \\
\hline $70-80$ & - & $5.0-12.7$ & - & - & 11.8 & - & - & 3.3 & {$[14]$} \\
\hline 74.33 & - & 10.41 & - & 80.68 & - & 6.68 & 4.73 & - & [54] \\
\hline
\end{tabular}

TABLE 7: Physical and mechanical strength of PALF.

\begin{tabular}{|c|c|c|c|c|c|c|c|c|}
\hline Density $\left(\mathrm{g} / \mathrm{cm}^{3}\right)$ & $\begin{array}{c}\text { Tensile } \\
\text { strength } \\
(\mathrm{MPa})\end{array}$ & $\begin{array}{l}\text { Young's } \\
\text { modulus } \\
(\mathrm{GPa})\end{array}$ & $\begin{array}{c}\text { Specific } \\
\text { strength } \\
\left(\mathrm{GPa} / \mathrm{g} / \mathrm{cm}^{3}\right)\end{array}$ & $\begin{array}{c}\text { Specific } \\
\text { modulus } \\
\left(\mathrm{GPa} / \mathrm{g} / \mathrm{cm}^{3}\right)\end{array}$ & $\begin{array}{c}\text { Elongation at } \\
\text { break }(\%)\end{array}$ & Dia. $(\mu \mathrm{m})$ & $\begin{array}{l}\text { Microfibril } \\
\text { angle }\end{array}$ & $\begin{array}{l}\text { PALF fibre } \\
\text { /reference }\end{array}$ \\
\hline 1.52 & $413-1627$ & $34.5-82.51$ & $0.3-1.1$ & $22.7-54.3$ & $1.6-3$ & $20-80$ & - & [55] \\
\hline 1.526 & 170 & 62.10 & 1.1 & 40.70 & 3 & - & - & {$[24]$} \\
\hline 1.44 & $413-1627$ & $34.5-82.51$ & - & - & 1.6 & - & - & {$[56,57]$} \\
\hline 1.526 & 413 & 62.10 & - & - & 1.6 & 50 & - & {$[58]$} \\
\hline \multirow[t]{2}{*}{1.07} & 126.60 & 4.405 & - & - & 2.2 & - & - & {$[22]$} \\
\hline & $413-1627$ & $34.5-82.5$ & - & - & 1.6 & $20-80$ & 14 & [14] \\
\hline 1.526 & 170 & 6.260 & - & - & 3 & - & - & [27] \\
\hline 1.52 & 170 & 6.21 & - & - & 3 & - & - & [59] \\
\hline 1.07 & 126.60 & 4.405 & - & - & 2.2 & - & - & {$[60]$} \\
\hline 1.526 & 413 & 6.5 & - & - & 1.6 & $30-60$ & - & {$[61]$} \\
\hline 1.526 & 170 & 62.10 & - & - & 3 & - & - & {$[62]$} \\
\hline 1.44 & $413-1627$ & $34.5-82.51$ & - & - & - & $20-80$ & $8-14$ & {$[63]$} \\
\hline 1.44 & $413-1627$ & $34.5-82.51$ & - & - & 1.6 & $20-80$ & - & [33] \\
\hline 1.44 & 170 & 6.26 & - & - & 1.6 & $5-30$ & 12 & {$[64]$} \\
\hline 1.526 & 413 & 4.2 & - & - & $3.0-4.0$ & 50 & 14 & {$[65]$} \\
\hline 1.440 & - & - & - & - & - & $1.56-4.5$ & $8-15$ & {$[66]$} \\
\hline- & 293.08 & 18.934 & - & - & 1.41 & $150-300$ & - & [67] \\
\hline
\end{tabular}

behaviour, and dielectric property. PALF shows good elastic property in cellulose type I structure. In comparison to other natural fibres PALF has high strength. The electrical properties show high anisotropy.

3.6. FTIR Spectra. FTIR spectroscopy is used to observe functional groups in natural fibres, such as hydroxyl group, carbonyl groups and vinyl groups, ketone group, and many more. It helps to identify the changes in chemical compound of natural fibres before and after the chemical treatments [123]. Table 8 shows the typical FTIR spectra of various untreated natural fibres hemp, sisal, jute, kapok, kenaf, and oil palm fibre along with PALF. The characteristic of the $\mathrm{O}-\mathrm{H}$ group is common for all, visible in between the intensity of $3338-3450 \mathrm{~cm}^{-1}$. The untreated fibres show common peaks corresponding C-H stretching and C-O stretching at 2924.2 and $1741.1 \mathrm{~cm}^{-1}$, respectively [69]. According to Jonoobi, in kenaf, the broad peak at $3338 \mathrm{~cm}^{-1}$ which appears in spectra is attributed to the $\mathrm{O}-\mathrm{H}$ frequency, whereas the peaks at $2899 \mathrm{~cm}^{-1}$ mainly take place from $\mathrm{C}-\mathrm{H}$ stretching [124]. Sreekala noted that the untreated oil palm fibre shows peaks corresponding $\mathrm{C}-\mathrm{O}$ stretching at $770 \mathrm{~cm}^{-1}$ and $\mathrm{C}-\mathrm{H}$ stretching at $2850 \mathrm{~cm}^{-1}$, whereas oil palm fibre shows another peak at $3450 \mathrm{~cm}^{-1}$ due to the $-\mathrm{O}-\mathrm{H}$ stretching [69].

FTIR spectra of holocellulose and $\alpha$-cellulose samples free from extractive of PALF are presented in Figure 2 [54]. The peak $3343 \mathrm{~cm}^{-1}$ represents $\mathrm{O}-\mathrm{H}$ groups in case of $\alpha$ cellulose sample. In holocellulose and free-extractive samples, hydroxyl stretching frequency displayed at $3,296 \mathrm{~cm}^{-1}$ and $3327 \mathrm{~cm}^{-1}$, respectively. For $\alpha$-cellulose sample, another peak frequency at $1725.25 \mathrm{~cm}^{-1}$ shows C-O bending frequency. While, in case of holocellulose and free extractive, the peak frequency at 1728 and $1733 \mathrm{~cm}^{-1}$ corresponds to the carbonyl peak frequencies, respectively. The sharp band 
TABLE 8: Infrared transmittance peaks $\left(\mathrm{cm}^{-1}\right)$ of untreated natural fibres [28, 68-70].

\begin{tabular}{lccccccc}
\hline Bond/stretching & PALF $\left(\mathrm{cm}^{-1}\right)$ & Hemp $\left(\mathrm{cm}^{-1}\right)$ & Sisal $\left(\mathrm{cm}^{-1}\right)$ & Jute $\left(\mathrm{cm}^{-1}\right)$ & Kapok $\left(\mathrm{cm}^{-1}\right)$ & Kenaf $\left(\mathrm{cm}^{-1}\right)$ & Oil palm fibre $\left(\mathrm{cm}^{-1}\right)$ \\
\hline -OH & 3349.9 & 3448 & 3447.2 & 3447.9 & 3419.7 & 3338 & 3450 \\
C-H & 2903.8 & 2920.5 & 2924.2 & 2918.8 & 2918.1 & 2899 & 2850 \\
C=O & 1737.4 & - & 1736.5 & 1737.2 & 1741.1 & 1736 & 1735 \\
C=C & 1608.3 & 1654 & 1653.9 & 1653.8 & 1596.1 & - & 1606 \\
C-H & 1374.2 & 1384.1 & 1384.1 & 1384.1 & 1383.6 & - & - \\
C-H & - & - & 1259.9 & 1255.6 & 1245.5 & - & - \\
\hline
\end{tabular}

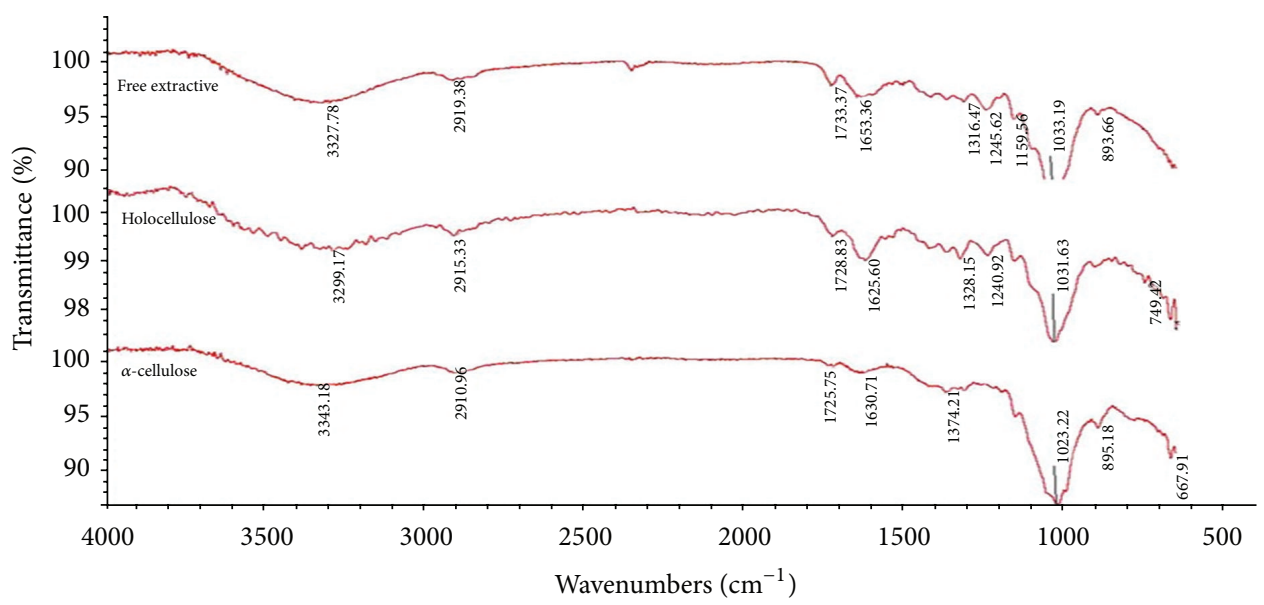

FIGURE 2: FTIR spectra of pineapple leaf fiber in various forms [54] (With Permission).

observed at $1733 \mathrm{~cm}^{-1}$ is due to the absorption of carbonyl stretching of ester and carboxyl groups which is most abundant in pineapple leaf hemicelluloses [54].

\section{Challenges for PALF as Reinforcement}

PALF shows lower degree of compatibility with hydrophobic polymers due to its hygroscopic nature. Existence of natural waxy substance on surface of fibre layer provides low surface tension, which does not allow a strong bond with polymer matrix. However, the literature suggests various methods to improve the fiber surface to make it suitable for good interfacial fibre/matrix bonding. Natural fibres reinforced polymers are susceptible to humidity and water absorption that causes a physical degradation of final product. High moisture content in fibre can cause swelling or dimensional defect at the time of composites preparing that affect the physical and mechanical property of the final product. [62]. At low temperature, water molecule faces obstacle by stiffness of polymer chain segments. Moisture diffusion into polymer depends on various factors such as molecule structure, polarity, crystallinity and the hardeners used in composite making [125].

\section{PALF Based Composite}

Natural fibres are focused study among researchers and industries, as a replacement of glass fibres to natural fibres. The rapid growth in research on environmental issues is acceleration factors to utilise natural fibres in coming decades. Recently, PALF is being utilised effectively in polymer matrix to develop composites with improved mechanical strength [126]. The outstanding mechanical properties of individual PALF are reflected in its ultimate product. Various research has been done to reinforce PALF with thermoset [73], thermoplastic [64], biodegradable plastics [25, 26], and natural rubber [127].

5.1. Epoxy Based PALF Reinforced Composite. Epoxy resin has excellent properties like adhesion, strength, low shrinkage, corrosion protection, and many other properties [128]. Although it is expensive resin, its mechanical and chemical properties are very good. Natural fibres like jute, flax, sisal, and bamboo fibres with epoxy reinforced have been studied [129-133]. In case of PALF there is no work done yet. PALF has a major problem related to adhesion with many polymer matrices. PALF is hydrophilic in nature and it does not have good compatibility with hydrophobic polymer. PALF contains waxy substance on its surface causing low surface tension which negatively affects the bonding with polymer matrix. To overcome this issue PALF surface is modified to improve bonding. In surface modification process reagents make fibres hydrophobic in nature and graft the fibres surface with resin matrix and some compatible polymers [134]. A number of researches have been carried out to improve the adhesion between PALFs and matrix, for example, cyanoethylation, alkalization, dewaxing, and grafting of acrylonitrile monomer [135]. These methods have 
been proved to be a very effective modification to enhance the adhesion property of PALFs with polymer matrix. Benzoylated PALF with alkali treatment are used to enhance the adhesion and tensile properties. The alkalization process makes the fibres surface rough and improved mechanical hold. A rough surface improves the affinity of epoxy matrix and interfacial adhesion made strong due to deposition of DGEBA resin on fibres surface. Furthermore PALF-epoxy composites will exhibit a positive result in interfacial bonding when combination of alkalization and DGEBA solution will be used. Such kinds of surface modification will enhance the flexural, tensile, and impact properties of epoxy composite [126].

5.2. Polyethylene Based PALF Reinforced Composites. A pineapple leaf fibre reinforced with polyethylene exhibits high performance composites [9]. In comparison to other natural fibres, pineapple leaf fibre (PALF) shows excellent mechanical and physical properties but the hydrophilic nature of PALF causes a negative impact. Thus, a chemical treatment such as alkali, isocyanate, saline, and permanganate was carried out to improve the water resistance. Peroxide modification is very helpful to reduce the hygroscopicity of fibres [136].

5.3. Polypropylene Based PALF Reinforced Composites. Pineapple leaf fibres (PALF) are renounced as possible and plentiful substitutes for the high-priced and nonrenewable synthetic fibres. PALF enhances the mechanical properties of the polymer matrix through its own high specific strength. PALF is multicellular, lignocellulosic and has very good mechanical properties. In study of stress behaviour of PALF reinforced polyethylene composite, stress is inversely proportional fibre content. Mechanical properties of polypropylenepineapple leaf fibre reinforced composites are reported. The tensile and flexural properties of composites are depending on volume fraction [60]. The recent study showed very useful composites with high-quality strength. PALF is being used as a reinforced agent in polyropylene matrix in the palce of pure resin, to improve the mechanical properties. Flexural modulus and flexural stress are directly related to the volume fraction. Though, value is insignificant due to fibre-to-fibre repulsion and dispersion problems. Researchers are mainly focused on improving the mechanical properties of PALF-PP composites and interfacial relation.

5.4. Vinyl Ester Based PALF Reinforced Composites. Now natural fibres are widely used in the research as a substitute of glass fibre (GF) in fibre reinforced plastics (FRP). In comparison to glass fibre, these natural fibres have lower densities, are economical, consume lesser energies during production, cause less or no abrasion to machines, and are not hazardous to health when inhaled [137]. In spite of these properties, pineapple leaf fibres are untouched in research areas especially for reinforcing plastics although this application is now becoming an important research area. Now polymers composite is focused on using pineapple leaf fibres for developing value added applications. Despite several merits, PALF possesses inherent demerits such as poor interfacial fibre-matrix adhesion and absorbing water. In the last two decades, a lot of researches have been carried out to optimize the problem of the interfacial adhesion between natural fibres and polymer matrices [82]. There is not much literature available on PALF-vinyl composites. Vinyl esters are strong, flexible, and less hydrophilic in nature [138]. Moreover, interfacial shear stress (IFSS) is the measurement of fibre-matrix adhesion which is always higher for natural fibre-vinyl ester compared to those of other matrices [139]. Most of the work on PALF-reinforced thermoset composites used hand lay-up method in sample preparation and very few if any reported the use of liquid compression moulding process. As reinforced matrix, both untreated and bleached PALF are using in the form of random and unidirectional PALF mats. To evaluate the viability of PALF-vinyl ester ecocomposites, there are many criteria of measurement, for instance, mechanical properties, water absorption, and thermal stability.

5.5. Polyester Based PALF Reinforced. PALF is obtained from the pineapple plant's leaves. Major compounds of PALF are cellulose (70-80\%), lignin (5-12\%), and ash (1.1) [140]. The recent study proved that by using different surface modified pineapple leaf fibres as reinforcing material can be used for polyester matrix. PALF fibre loading up to $30 \%$ by weight with polyester showed significant increment in flexural strength, tensile strength, and impact strength. Toughness of composite material is reached up to the benchmark of engineering materials. Surface modification by chemical treatment can enhance the strength of individual fibers and it can help to develop better mechanical strength PALF/polyester composite for commercial purpose [71].

5.6. Polycarbonate Based PALF Composite. A poor contact between PALF and matrix are prone to moisture intake and ultimately degradation through insects and pests [31, 141]. Thus, fibre surface modification is an important and necessary step to reduce the polarity of fibre. There are many methods like alkaline treatment [142], grafting with maleic anhydride copolymer [34], saline coupling agent such as c-aminopropyl trimethoxy silane (Z-6011) and c methacrylate propyl trimethoxy saline (Z-6030) $[143,144]$. Polycarbonate (PC) is an amorphous thermoplastic resin. It provides numerous vital and important characteristics such as lucidity, dimensional strength, high impact strength, and high heat resistant and flame resistance. Though there are some limitations of using the PALF in some applications. At low temperatures, it becomes softer and easy to remove from mould [145]. There are very few research works published on the PALF reinforced with polymers [146].

5.7. Low Density Polyethylene Based PALF Composite. Melt mixing and solution mixing techniques have been used in preparation of PALF reinforced LDPE composites. Solution mixed technique shows a better tensile strength than melt mixed technique. Relation of fibre size, loading $\%$, and orientation with mechanical properties has been studied. Through fibre distribution curve and scanning electron micrographs, 
TABLE 9: PALF biocomposites and hybrid composites with thermosets and thermoplastics.

\begin{tabular}{lcc}
\hline Natural fibre & Resin & References \\
\hline PALF & Vinyl ester & {$[71]$} \\
PALF & Epoxy & {$[72]$} \\
PALF & Polycarbonate & {$[35]$} \\
PALF & Polypropylene & {$[60]$} \\
PALF & Polyester & {$[73]$} \\
PALF & Low density & {$[74]$} \\
PALF & polyethylene & {$[75]$} \\
PALF + banana & Polyethylene & {$[76]$} \\
PALF + disposable & Epoxy resin & \\
chopstick hybrid & PLA \& polybutylene & {$[77]$} \\
fibre & succinate (PBS) & \\
PALF + kenaf & HDPE & {$[78]$} \\
PALF + glass fibre & Polyester & {$[79]$} \\
\hline
\end{tabular}

it is possible to analyse fibre rupture and damage during composite making. Fibre length of $6 \mathrm{~mm}$ length was found to be suitable for PALF reinforced with LDPE. Mechanical properties are found to be improved and elongation at break is inversely proportional to fibre loading. In comparison to random and transverse orientation, longitudinal orientation of fibres showed better mechanical properties of composites. PALF-LDPE composites are ecofriendly, biodegradable and exhibit superior performance than any other cellulose-fibrereinforced LDPE systems [74].

\section{PALF Based Hybrid Composites}

Various combinations of natural lignocellulosic composite are promising interest of researchers. It provides wide range of results and properties which is very difficult to achieve through a single type of reinforcement. This type of matrix is generally used for the fibre having good interaction between matrix and fibres and together gives a better mechanical performance $[147,148]$. Thus, hybrid composite is the mixture of two different types of fibres reinforced into a matrix. It has various improved qualities which help to make it best composite. Individual strength of fibres is combined to achieve improved composite with better efficiency. Many researches are in progress for partially or fully replacement to glass fibres (GF) by natural fibres. GF has very good quality of reinforcement along with natural fibres like sisal, jute, pineapple, hemp, and so forth $[149,150]$. Composites and hybrid composites with PALF are shown in Table 9. Mechanical characteristic of hybrid composite and GF is studied by Thomas et al. [151, 152]. Idicula et al. studied the well mixed random orientation of banana/sisal hybrid fibre reinforcement with polyester composite [153]. Transformation maximum stress between fibres and matrix has been calculated for the composite of banana and sisal fibre ratio $3: 1$, showing lowest impact strength. There is another composite of natural fibre reinforced with short carbon and kenaf fibre hybrid system [154]

On the basis of these studies, the aim of this research is to develop a high-performance, cost-effective, and lightweight pineapple leaf fibres and GF as the reinforcement based hybrid composites. Utilization of pineapple leaf with disposable chopsticks is very popular $[155,156]$. Pineapple leaf fibre $(2.3-3.9 \mathrm{~mm})$ and recycled disposable chopstick fibres were integrated into PLA and PBS. The optimum ratio and content of the hybrid fibres were investigated in order to obtain the best thermal and mechanical properties.

\section{PALF Applications and Future Prospects}

PALF is generally used in making threads for textile fabrics from several decades. A future prospect of diversified application of PALF is presented in Figure 3. Present application of PALF for various purposes is textile, sports item, baggage, automobiles, cabinets, mats, and so forth. Surface modified PALF is introduced for making machinery parts like belt cord, conveyor belt cord, transmission cloth, air-bag tying cords, and some cloths for industry uses [157]. PALF is very good for carpet making because of its chemical processing, dyeing behaviour, and aesthetically pleasing fabric [158]. The use of pineapple leaf fibre can be considered relatively as new in the paper manufacturing industry in Malaysia [159]. PALF can be suitable for various other applications such as cosmetics, medicine, and biopolymers coating for chemicals [160-162].

The pineapple leave fibre is one of the natural fibres, having highest cellulosic content nearly $80 \%$. Its density is similar to the other natural fibres while Young's modulus shows highest tensile strength when compared to other natural fibres. These properties are suitable for its application as building and construction materials, automotive components, and furniture. From this review it is clear that limited work has been done on thermal, electrical, dynamic, and mechanical properties. Till now, PALF has been studied as being reinforced with $\mathrm{PP}$ and unsaturated polyester only, so it is required to understand its behaviour with other resins also in relation to fabricated biocomposites and hybrid composites. PALF is widely accepted in textile sector and already used in our daily life materials but we attribute that further study will enhance the application in various other exiting products.

\section{Conclusions}

Pineapple leaf fibre is very common in tropical regions and very simple to extract fibres from its leaves. The utilization of pineapple leaf fibre in composite material is a new source of materials which can be economic, ecofriendly, and recyclable. However, the main issue of PALF is its hydroscopic nature, which makes a big hurdle for fibre utilization as a reinforced material in polymer composites. Surface modification of PALF is required to improve for good interfacial adhesion of PALF with polymers in fabrication of polymer composites. Synthetic fibres can be replaced or partially substituted with PALF in fabrication of composite 


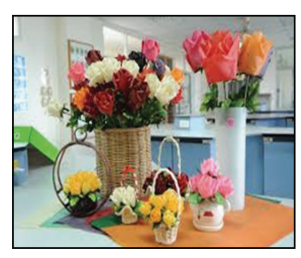

Decoration

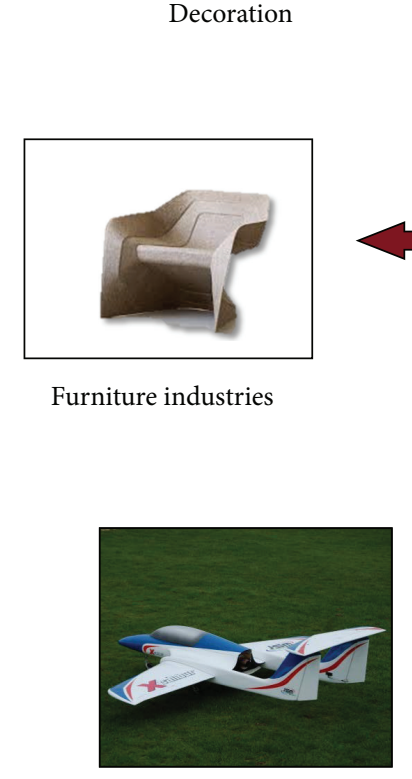

Aerospace industries

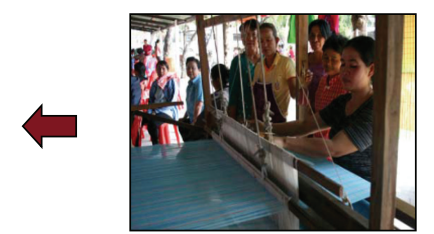

Fabric industries

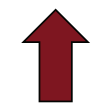

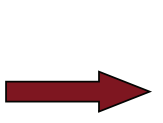



Sports industries

FIGURE 3: Various present and future applications of pineapple leaves.

products for different applications. The author concluded various recent works reported on chemical modification of PALF and physical and mechanical properties of PALF reinforced polymer composites and its hybrid. Pineapple is one of the natural fibres having highest cellulosic content nearly $80 \%$. Density of PALF is similar to other natural fibres while Young's modulus is very high, and tensile strength is highest among the related natural fibres. These properties are suitable for its application as building and construction materials, automotive components, and furniture. From this review it is clear that limited work has been carried out on thermal properties such as, electrical properties, thermal conductivity, dynamic mechanical analysis, and modelling of mechanical properties of PALF reinforced polymer composites. In most of the examples, PALF fibres are reinforced with $\mathrm{PP}$ and unsaturated polyester only, so it is required to study the behaviour of PALF with other resins to get it wider application in biocomposites and hybrid composites manufacturing. PALF is widely accepted in textile sector and already used in our daily life materials but we attributed that further study will enhance its application in development of various existing products.

\section{Conflict of Interests}

The authors declare that there is no conflict of interests regarding the publication of this paper.

\section{Acknowledgment}

The authors are thankful to the Ministry of Science and Technology (MOSTI), E-Science Project no. 03-01-04-SF 1855 for supporting this research work.

\section{References}

[1] M. Jawaid and H. P. S. Abdul Khalil, "Cellulosic/synthetic fibre reinforced polymer hybrid composites: a review," Carbohydrate Polymers, vol. 86, no. 1, pp. 1-18, 2011.

[2] Faostat, Food and Agriculture Organization of the United Nations, 2011, http://www.fao.org/.

[3] J. M. Kenny, "Natural fibre composites in the European automotive industry," in Proceedings of the 6th International Conference on Wood Fibre-Plastic Composites, 2001.

[4] W. D. Brouwer, "Natural fibre composites: where can flax compete with glass?" SAMPE Journal, vol. 36, no. 6, pp. 18-23, 2000.

[5] T. Peijs, "Composites turn green," in Proceedings of the Swedish Institute of Composite Conference, Piteå, Sweden, 2000.

[6] U. K. D. N. Chand, "Effect of coupling agent on high stress abrasive wear of chopped jute/PP composite," Wear, vol. 261, 2006.

[7] M. S. Sreekala, M. G. Kumaran, and S. Thomas, "Oil palm fibers: morphology, chemical composition, surface modification, and mechanical properties," Journal of Applied Polymer Science, vol. 66, no. 5, pp. 821-835, 1997. 
[8] P. J. Herrera-Franco and A. Valadez-González, "A study of the mechanical properties of short natural-fiber reinforced composites," Composites Part B: Engineering, vol. 36, no. 8, pp. 597-608, 2005.

[9] M. Abdelmouleh, S. Boufi, M. N. Belgacem, and A. Dufresne, "Short natural-fibre reinforced polyethylene and natural rubber composites: effect of silane coupling agents and fibres loading," Composites Science and Technology, vol. 67, no. 7-8, pp. 16271639, 2007.

[10] V. Tserki, N. E. Zafeiropoulos, F. Simon, and C. Panayiotou, "A study of the effect of acetylation and propionylation surface treatments on natural fibres," Composites Part A: Applied Science and Manufacturing, vol. 36, no. 8, pp. 1110-1118, 2005.

[11] L. Yan, N. Chouw, and X. Yuan, "Improving the mechanical properties of natural fibre fabric reinforced epoxy composites by alkali treatment," Journal of Reinforced Plastics and Composites, vol. 31, no. 6, pp. 425-437, 2012.

[12] Q. Liu, T. Stuart, M. Hughes, H. S. S. Sharma, and G. Lyons, "Structural biocomposites from flax-part II: the use of PEG and PVA as interfacial compatibilising agents," Composites Part A: Applied Science and Manufacturing, vol. 38, no. 5, pp. 14031413, 2007.

[13] L. S. M. Carus, "Targets for bio-based composites and natural fibres," JEC Composites Magazine, vol. 8, no. 63, p. 31, 2011.

[14] A. K. Mohanty, M. Misra, and L. T. Drzal, Natural Fibres, Biopolymers and Biocomposites, Taylor \& Francis, CRC Press, 2005.

[15] K. G. Satyanarayana, S. G. K. Pillai, B. C. Pai, and K. Sukumaran, "Lignocellulosic fibre reinforced polymer composite," in Handbook of Ceramic and Composites, N. P. Cheremisinoff, Ed., vol. 1, Marcel Dekker, New York, NY, USA, 1990.

[16] K. G. Satyanarayana, K. Sukumaran, P. S. Mukherjee, C. Pavithran, and S. G. K. Pillai, "Natural fibre-polymer composites," Cement and Concrete Composites, vol. 12, no. 2, pp. 117-136, 1990.

[17] V. D. S. U. S. Bongarde, "Review on natural fiber reinforcement polymer composites," International Journal of Engineering Science and Innovative Technology, vol. 3, no. 2, pp. 431-436, 2014.

[18] C. M. Ma, H. Tseng, and H. Wu, "Blocked diisocyanate polyester-toughened novolak-type phenolic resin: synthesis, characterization, and properties of composites," Journal of Applied Polymer Science, vol. 69, no. 6, pp. 1119-1127, 1998.

[19] T. Schuh and U. Gayer, "Automotive applications of natural fiber composites. Benefits for the environment and competitiveness with man-made materials," in Lignocellulosic-Plastics Composites, A. L. Leao, F. X. Carvalho, and E. Frollini, Eds., 1997.

[20] R. M. Rowell, A. R. Sanadi, D. F. Caulfield, and R. E. Jacobson, "Utilization of natural fibres in plastic composites-problems and opportunities," in Lignocellulosic-Plastics Composites, 1997.

[21] L. Yan, N. Chouw, and K. Jayaraman, "Flax fibre and its composites-a review," Composites Part B: Engineering, vol. 56, pp. 296-317, 2014.

[22] R. M. N. Arib, S. M. Sapuan, M. A. M. M. Hamdan, M. T. Paridah, and H. M. D. K. Zaman, "A literature review of pineapple fibre reinforced polymer composites," Polymers and Polymer Composites, vol. 12, no. 4, pp. 341-348, 2004.

[23] C. Pavithran, P. S. Mukherjee, M. Brahmakumar, and A. D. Damodaran, "Impact properties of natural fibre composites," Journal of Materials Science Letters, vol. 6, no. 8, pp. 882-884, 1987.
[24] S. Mishra, M. Misra, S. S. Tripathy, S. K. Nayak, and A. K. Mohanty, "Potentiality of pineapple leaf fibre as reinforcement in PALF-polyester composite: Surface modification and mechanical performance," Journal of Reinforced Plastics and Composites, vol. 20, no. 4, pp. 321-334, 2001.

[25] S. Luo and A. N. Netravali, "Interfacial and mechanical properties of environment-friendly 'green' composites made from pineapple fibers and poly(hydroxybutyrate-co-valerate) resin," Journal of Materials Science, vol. 34, no. 15, pp. 3709-3719, 1999.

[26] W. Liu, M. Misra, P. Askeland, L. T. Drzal, and A. K. Mohanty, “'Green' composites from soy based plastic and pineapple leaf fiber: fabrication and properties evaluation," Polymer (Guildf), vol. 46, no. 8, pp. 2710-2721, 2005.

[27] J. George, S. S. Bhagawan, and S. Thomas, "Effects of environment on the properties of low-density polyethylene composites reinforced with pineapple-leaf fibre," Composites Science and Technology, vol. 58, no. 9, pp. 1471-1485, 1998.

[28] R. K. Samal and M. C. Ray, "Effect of chemical modifications on FTIR spectra. II. Physicochemical behavior of pineapple leaf fiber (PALF)," Journal of Applied Polymer Science, vol. 64, no. 11, pp. 2119-2125, 1997.

[29] J. George, S. S. Bhagawan, N. Prabhakaran, and S. Thomas, "Short pineapple-leaf-fiber-reinforced low-density polyethylene composites," Journal of Applied Polymer Science, vol. 57, no. 7, pp. 843-854, 1995.

[30] N. Lopattananon, K. Panawarangkul, K. Sahakaro, and B. Ellis, "Performance of pineapple leaf fiber-natural rubber composites: the effect of fiber surface treatments," Journal of Applied Polymer Science, vol. 102, no. 2, pp. 1974-1984, 2006.

[31] A. O’Donnell, M. A. Dweib, and R. P. Wool, "Natural fiber composites with plant oil-based resin," Composites Science and Technology, vol. 64, no. 9, pp. 1135-1145, 2004.

[32] M. Abdelmouleh, S. Boufi, M. N. Belgacem, A. Dufresne, and A. Gandini, "Modification of cellulose fibers with functionalized silanes: effect of the fiber treatment on the mechanical performances of cellulose-thermoset composites," Journal of Applied Polymer Science, vol. 98, no. 3, pp. 974-984, 2005.

[33] A. K. Mohanty, M. A. Khan, and G. Hinrichsen, "Influence of chemical surface modification on the properties of biodegradable jute fabrics-polyester amide composites," Composites Part A: Applied Science and Manufacturing, vol. 31, no. 2, pp. 143-150, 2000.

[34] B. Jing, W. Dai, S. Chen, T. Hu, and P. Liu, "Mechanical behavior and fracture toughness evaluation of $\mathrm{K}$ resin grafted with maleic anhydride compatibilized polycarbonate/K resin blends," Materials Science and Engineering A, vol. 444, no. 1-2, pp. 84-91, 2007.

[35] P. Threepopnatkul, N. Kaerkitcha, and N. Athipongarporn, "Effect of surface treatment on performance of pineapple leaf fiber-polycarbonate composites," Composites Part B: Engineering, vol. 40, no. 7, pp. 628-632, 2009.

[36] M. Drzal, L. T. Mohanty, and A. K. Misra, "Bio-composite materials as alternatives to petroleum-based composites for automotive applications," Magnesium, vol. 40, pp. 1-3, 2001.

[37] H. Savastano Jr., P. G. Warden, and R. S. P. Coutts, "Brazilian waste fibres as reinforcement for cement-based composites," Cement and Concrete Composites, vol. 22, no. 5, pp. 379-384, 2000.

[38] R. M. Rowell, J. S. Han, and J. S. Rowell, "Characterization and factors effecting fiber properties," in Natural Polymers and Agrofibers Based Composites, pp. 115-134, 2000. 
[39] J. A. Foulk, D. E. Akin, R. B. Dodd, and D. D. McAlister III, "Flax fiber: potential for a new crop in the Southeast," in Trends in New Crops and New Uses, pp. 361-370, ASHS Press, 2002.

[40] L. Y. Mwaikambo, "Review of the history, properties and application of plant fibres," African Journal of Science and Technology, vol. 7, no. 2, pp. 120-133, 2006.

[41] S. Taj, M. A. Munawar, and S. U. Khan, "Natural fiber-reinforced polymer composites," Proceedings of the Pakistan Academy of Sciences, vol. 44, no. 2, pp. 129-144, 2007.

[42] O. Faruk, A. K. Bledzki, H.-P. Fink, and M. Sain, "Biocomposites reinforced with natural fibers: 2000-2010," Progress in Polymer Science, vol. 37, no. 11, pp. 1552-1596, 2012.

[43] M. J. John and S. Thomas, "Biofibres and biocomposites," Carbohydrate Polymers, vol. 71, no. 3, pp. 343-364, 2008.

[44] X. Li, L. G. Tabil, and S. Panigrahi, "Chemical treatments of natural fiber for use in natural fiber-reinforced composites: a review," Journal of Polymers and the Environment, vol. 15, no. 1, pp. 25-33, 2007.

[45] P. Wambua, J. Ivens, and I. Verpoest, "Natural fibres: can they replace glass in fibre reinforced plastics?" Composites Science and Technology, vol. 63, no. 9, pp. 1259-1264, 2003.

[46] H. Uhlig, Industrial Enzymes and Their Applications, John Wiley \& Sons, New York, NY, USA, 1998.

[47] R. M. Heinicke and W. A. Gortner, "Stem bromelain-a new protease preparation from pineapple plants," Economic Botany, vol. 11, no. 3, pp. 225-234, 1957.

[48] D. Verma, P. C. Gope, A. Shandilya, A. Gupta, and M. K. Maheshwari, "Coir fibre reinforcement and application in polymer composites: a review," Journal of Materials and Environmental Science, vol. 4, no. 2, pp. 263-276, 2013.

[49] M. M. Kabir, H. Wang, K. T. Lau, and F. Cardona, "Chemical treatments on plant-based natural fibre reinforced polymer composites: an overview," Composites Part B: Engineering, vol. 43, no. 7, pp. 2883-2892, 2012.

[50] S. V. Siregar and S. Utama, "Type of earnings management and the effect of ownership structure, firm size, and corporategovernance practices: evidence from Indonesia," International Journal of Accounting, vol. 43, no. 1, pp. 1-27, 2008.

[51] S. A. B. Yahya and Y. Yusof, "Comprehensive review on the utilization of PALF," Advanced Materials Research, vol. 701, pp. 430-434, 2013.

[52] S. K. Bhaduri and S. K. Sen, "Structural studies of an acidic polysaccharide isolated from the leaf fibre of pineapple (Ananas comosus MERR.)," Carbohydrate Research, vol. 121, pp. 211-220, 1983.

[53] S. Banika, D. Nag, and S. Debnath, "Utilization of pineapple leaf agro-waste for extraction of fibre and the residual biomass for vermicomposting," Indian Journal of Fibre and Textile Research, vol. 36, no. 2, pp. 172-177, 2011.

[54] W. O. Wan Nadirah, M. Jawaid, A. A. Al Masri, H. P. S. Abdul Khalil, S. S. Suhaily, and A. R. Mohamed, "Cell wall morphology, chemical and thermal analysis of cultivated pineapple leaf fibres for industrial applications," Journal of Polymers and the Environment, vol. 20, no. 2, pp. 404-411, 2012.

[55] D. B. S. Fakirov, Wood Fibre Thermoplastic Composite: Processing Properties and Future Developments, Hanser, Munich, Germany, 2007.

[56] K. G. Satyanarayana, C. K. S. Pillai, K. Sukumaran, S. G. K. Pillai, P. K. Rohatgi, and K. Vijayan, "Structure property studies of fibres from various parts of the coconut tree," Journal of Materials Science, vol. 17, no. 8, pp. 2453-2462, 1982.
[57] S. Kalia, B. S. Kaith, and I. Kaur, "Pretreatments of natural fibers and their application as reinforcing material in polymer composites-a review," Polymer Engineering and Science, vol. 49, no. 7, pp. 1253-1272, 2009.

[58] L. U. Devi, S. S. Bhagawan, and S. Thomas, "Dynamic mechanical properties of pineapple leaf fiber polyester composites," Polymer Composites, vol. 32, no. 11, pp. 1741-1750, 2011.

[59] M. S. Huda, L. T. Drzal, A. K. Mohanty, and M. Misra, "Effect of chemical modifications of the pineapple leaf fiber surfaces on the interfacial and mechanical properties of laminated biocomposites," Composite Interfaces, vol. 15, no. 2-3, pp. 169191,2008

[60] R. M. N. Arib, S. M. Sapuan, M. M. H. M. Ahmad, M. T. Paridah, and H. M. D. K. Zaman, "Mechanical properties of pineapple leaf fibre reinforced polypropylene composites," Materials and Design, vol. 27, no. 5, pp. 391-396, 2006.

[61] L. Uma Devi, S. S. Bhagawan, and S. Thomas, "Dynamic mechanical analysis of pineapple leaf/glass hybrid fiber reinforced polyester composites," Polymer Composites, vol. 31, no. 6, pp. 956-965, 2010.

[62] L. U. Devi, K. Joseph, K. C. M. Nair, and S. Thomas, "Ageing studies of pineapple leaf fiber-reinforced polyester composites," Journal of Applied Polymer Science, vol. 94, no. 2, pp. 503-510, 2004.

[63] U. Hujuri, S. K. Chattopadhay, R. Uppaluri, and A. K. Ghoshal, Effect of Maleic Anhydride Grafted Polypropylene on the Mechanical and Morphological Properties of Chemically Modified Short-Pineapple-Leaf-Fiber-Reinforced Polypropylene Composites, Wiley InterScience, 2007.

[64] J. George, K. Joseph, S. S. Bhagawan, and S. Thomas, "Influence of short pineapple fiber on the viscoelastic properties of lowdensity polyethylene," Materials Letters, vol. 18, no. 3, pp. 163170, 1993.

[65] M. Idicula, A. Boudenne, L. Umadevi, L. Ibos, Y. Candau, and S. Thomas, "Thermophysical properties of natural fibre reinforced polyester composites," Composites Science and Technology, vol. 66, no. 15, pp. 2719-2725, 2006.

[66] K. G. Satyanarayana, J. L. Guimarães, and F. Wypych, "Studies on lignocellulosic fibers of Brazil. Part I: source, production, morphology, properties and applications," Composites Part A: Applied Science and Manufacturing, vol. 38, no. 7, pp. 1694-1709, 2007.

[67] A. R. Mohamed, S. M. Sapuan, M. Shahjahan, and A. Khalina, "Characterization of pineapple leaf fibers from selected Malaysian cultivars," Journal of Food, Agriculture and Environment, vol. 7, no. 1, pp. 235-240, 2009.

[68] L. Y. Mwaikambo and M. P. Ansell, "Chemical modification of hemp, sisal, jute, and kapok fibers by alkalization," Journal of Applied Polymer Science, vol. 84, no. 12, pp. 2222-2234, 2002.

[69] M. S. Sreekala, M. G. Kumaran, S. Joseph, M. Jacob, and S. Thomas, "Oil palm fibre reinforced phenol formaldehyde composites: influence of fibre surface modifications on the mechanical performance," Applied Composite Materials, vol. 7, no. 5-6, pp. 295-329, 2000.

[70] N. I. A. Razak, N. A. Ibrahim, N. Zainuddin, M. Rayung, and W. Z. Saad, "The influence of chemical surface modification of kenaf fiber using hydrogen peroxide on the mechanical properties of biodegradable kenaf fiber/poly(lactic acid) composites," Molecules, vol. 19, no. 3, pp. 2957-2968, 2014.

[71] A. R. Mohamed, S. M. Sapuan, and A. Khalina, "Selected properties of hand-laid and compression molded vinyl ester and 
pineapple leaf fiber (PALF)-reinforced vinyl ester composites," International Journal of Mechanical and Materials Engineering, vol. 5, no. 1, pp. 68-73, 2010.

[72] Y. Payae and N. Lopattananon, "Adhesion of pineapple-leaf fiber to epoxy matrix: the role of surface treatments," Songklanakarin Journal of Science and Technology, vol. 31, no. 2, pp. 189-194, 2009.

[73] S. Mishra, M. Misra, S. S. Tripathy, S. K. Nayak, and A. K. Mohanty, "Potentiality of pineapple leaf fibre as reinforcement in PALF-polyester composite: surface modification and mechanical performance," Journal of Reinforced Plastics and Composites, vol. 20, no. 4, pp. 321-334, 2001.

[74] J. George, S. S. Bhagawan, and S. Thomas, "Effects of environment on the properties of low-density polyethylene composites reinforced with pineapple-leaf fibre," Composites Science and Technology, vol. 58, no. 9, pp. 1471-1485, 1998.

[75] J. George, S. S. Bhagawan, and S. Thomas, "Improved interactions in chemically modified pineapple leaf fiber reinforced polyethylene composites," Composite Interfaces, vol. 5, no. 3, pp. 201-223, 1998.

[76] J. Madhukiran, S. S. Rao, and S. Madhusudan, "Tensile and hardness properties of banana/pineapple natural fibre reinforced hybrid composites," International Journal of Engineering Research \& Technology, vol. 2, no. 7, pp. 1260-1264, 2013.

[77] Y.-F. Shih, W.-C. Chang, W.-C. Liu, C.-C. Lee, C.-S. Kuan, and Y.-H. Yu, "Pineapple leaf/recycled disposable chopstick hybrid fiber-reinforced biodegradable composites," Journal of the Taiwan Institute of Chemical Engineers, vol. 45, no. 4, pp. 2039-2046, 2014.

[78] I. S. Aji, E. S. Zainudin, A. Khalina, S. M. Sapuan, and M. D. Khairul, "Studying the effect of fiber size and fiber loading on the mechanical properties of hybridized kenaf/PALF-reinforced HDPE composite," Journal of Reinforced Plastics and Composites, vol. 30, no. 6, pp. 546-553, 2011.

[79] L. U. Devi, S. S. Bhagawan, K. C. M. Nair, and S. Thomas, "Water absorption behavior of PALF/GF hybrid polyester composites," Polymer Composites, vol. 32, no. 3, pp. 335-346, 2011.

[80] B. Madsen, Properties of plant fibre yarn polymer composites [Ph.D. thesis], Technical University of Denmark, Lyngby, Denmark, 2004.

[81] A. K. Bledzki and J. Gassan, "Composites reinforced with cellulose based fibres," Progress in Polymer Science, vol. 24, no. 2, pp. 221-274, 1999.

[82] M. J. John and R. D. Anandjiwala, "Recent developments in chemical modification and characterization of natural fiberreinforced composites," Polymer Composites, vol. 29, no. 2, pp. 187-207, 2008.

[83] L. Y. Mwaikambo and M. P. Ansell, "The effect of chemical treatment on the properties of hemp, sisal, jute and kapok for composite reinforcement," Angewandte Makromolekulare Chemie, vol. 272, no. 4753, pp. 108-116, 1999.

[84] D. N. Saheb and J. P. Jog, "Natural fiber polymer composites: a review," Advances in Polymer Technology, vol. 18, no. 4, pp. 351363, 1999.

[85] L. T. Drzal, A. K. Mohanty, R. Burgueño, and M. Misra, "Biobased structural composite materials for housing and infrastructure applications: opportunities and challenges," in NSF/PATH Housing Research Agenda, pp. 129-140, 2004.

[86] L. T. D. A. K. Mohanty and M. Misra, "The influence of surface modifications on performance of short henequen fibre polypropylene composite," in Proceedings of the Midwest
Advanced Materials and Processing Conference (SAMPE' 00), Dearborn, Mich, USA, 2000.

[87] S. K. N. J. Rout, M. Misra, and A. K. Mohanty, Studies on Aqueous Co Polymerization of MMA onto Chemically Modified Coir Fibre and Its Effect on Mechanical Performance of Fibre, Industry and R \& D Organization, New Delhi, India, 1998.

[88] Agriculture and Consumer Protection, "Application of natural fibre composites in the development of rural societies..., FAO Corporate Document Repository, http://www.fao.org/docrep/ 007/ad416e/ad416e06.htm.

[89] J. Foulk, D. Akin, and R. Dodd, "New low cost flax fibres for composites," in Proceedings of the Society of Automotive Engineers World Congress and Exposition, 2000.

[90] K. G. Satyanarayana, G. G. C. Arizaga, and F. Wypych, "Biodegradable composites based on lignocellulosic fibers-an overview," Progress in Polymer Science, vol. 34, no. 9, pp. 9821021, 2009.

[91] A. van Tran, "Chemical analysis and pulping study of pineapple crown leaves," Industrial Crops and Products, vol. 24, no. 1, pp. 66-74, 2006.

[92] B. Khadi and Village Industries Commission, "Fiber Industry".

[93] D. P. Bartholomew, R. E. Paull, and K. G. Rohrbach, The Pineapple: Botany, Production, and Uses, 2003.

[94] A. R. Rahmat, A. Hassan, and M. Mokhtar, "Characterization and treatments of pineapple leaf fibre thermoplastic composite for construction application," Project Report, Universiti Teknologi Malaysia, Johor, Malaysia, 2007.

[95] S. Ketnawa, S. Rawdkuen, and P. Chaiwut, "Two phase partitioning and collagen hydrolysis of bromelain from pineapple peel Nang Lae cultivar," Biochemical Engineering Journal, vol. 52, no. 2-3, pp. 205-211, 2010.

[96] A. Schieber, F. C. Stintzing, and R. Carle, "By-products of plant food processing as a source of functional compounds-recent developments," Trends in Food Science and Technology, vol. 12, no. 11, pp. 401-413, 2001.

[97] G. Walsh, Protein Biochemistry and Biotechnology, John Wiley \& Sons, New York, NY, USA, 2002.

[98] D. J. Cathcart, "The importance of maintaining bromeliad imports," The Florida Entomologist, vol. 78, no. 1, pp. 16-21, 1995.

[99] B. M. Cherian, A. L. Leão, S. F. de Souza et al., "Cellulose nanocomposites with nanofibres isolated from pineapple leaf fibers for medical applications," Carbohydrate Polymers, vol. 86, no. 4, pp. 1790-1798, 2011.

[100] C. T. C. Py and J. J. Lacoeuilhe, The Pineapple-Cultivation and Uses, Maisonneuve \& Larose, Quae, Paris, France, 1987.

[101] M. Bengtsson, P. Gatenholm, and K. Oksman, "The effect of crosslinking on the properties of polyethylene/wood flour composites," Composites Science and Technology, vol. 65, no. 10, pp. 1468-1479, 2005.

[102] J. George, M. S. Sreekala, and S. Thomas, "A review on interface modification and characterization of natural fiber reinforced plastic composites," Polymer Engineering and Science, vol. 41, no. 9, pp. 1471-1485, 2001.

[103] B. M. Cherian, A. L. Leão, S. F. de Souza, S. Thomas, L. A. Pothan, and M. Kottaisamy, "Isolation of nanocellulose from pineapple leaf fibres by steam explosion," Carbohydrate Polymers, vol. 81, no. 3, pp. 720-725, 2010.

[104] B. K. Das, A. C. Chakravarty, M. K. Sinha, and S. K. Ghosh, "Use of polyethylene monofilament in spinning core yarn of jute," Man Made Textile in India, vol. 21, no. 9, pp. 494-498, 1978. 
[105] S. K. Ghosh, M. K. Sinha, S. K. Dey, and S. K. Bhaduri, "Processing of pineapple leaf fibre in cotton machinery," Text Trends, vol. 14, no. 10, 1982.

[106] A. Rahman, "Study on modified pineapple leaf fiber," Journal of Textile and Apparel, Technology and Management, vol. 7, no. 2, pp. 1-16, 2011.

[107] A. K. Mohanty, M. Misra, and G. Hinrichsen, "Biofibres, biodegradable polymers and biocomposites: an overview," Macromolecular Materials and Engineering, vol. 276-277, pp. 124, 2000.

[108] P. Omojasola, O. Jilani, and S. Ibiyemi, "Cellulase production by some fungi cultured on pineapple waste," Natural Science, vol. 6, no. 2, pp. 64-79, 2008.

[109] S. K. Dey, G. K. Bhattacharyya, and S. K. Bhattacharyya, "Magic yarns from ramie and pineapple-a new dimension in 21st century," in Proceedings of the 20th Indian Engineering Congress, p. 69, Kolkata, India, December 2005.

[110] M. K. Sinha, "A review of processing technology for the utilisation of agro-waste fibres," Agricultural Wastes, vol. 4, no. 6, pp. 461-475, 1982.

[111] N. Debasis and D. Sanjoy, "A pineapple leaf fibre decorticator assembly," India Patents 2334/DEL/2007A, 2007.

[112] R. Kannojiya, K. Gaurav, R. Ranjan, N. K. Tiyer, and K. M. Pandey, "Extraction of pineapple fibres for making commercial products," Journal of Environmental Research and Development, vol. 7, no. 4, pp. 1385-1390, 2013.

[113] S. Banik, M. K. Basak, D. Paul et al., "Ribbon retting of jute-a prospective and eco-friendly method for improvement of fibre quality," Industrial Crops and Products, vol. 17, no. 3, pp. 183-190, 2003.

[114] N. Kengkhetkit and T. Amornsakchai, "Utilisation of pineapple leaf waste for plastic reinforcement: 1. A novel extraction method for short pineapple leaf fiber," Industrial Crops and Products, vol. 40, no. 1, pp. 55-61, 2012.

[115] Technical Association of the Pulp and Paper Industry, TAPPI Standard and Suggested Methods, Technical Association of the Pulp and Paper Industry, New York, NY, USA, 1991.

[116] H. P. S. A. Khalil, M. S. Alwani, and A. K. M. Omar, "Distribution , and cell wall structure of malaysian plant waste fibers," BioResources, vol. 1, pp. 220-232, 2006.

[117] D. Kumar, V. K. Jain, G. Shanker, and A. Srivastava, "Utilisation of fruits waste for citric acid production by solid state fermentation," Process Biochemistry, vol. 38, no. 12, pp. 1725-1729, 2003.

[118] S. B. Imandi, V. V. R. Bandaru, S. R. Somalanka, S. R. Bandaru, and H. R. Garapati, "Application of statistical experimental designs for the optimization of medium constituents for the production of citric acid from pineapple waste," Bioresource Technology, vol. 99, no. 10, pp. 4445-4450, 2008.

[119] N. Reddy and Y. Yang, "Biofibers from agricultural byproducts for industrial applications," Trends in Biotechnology, vol. 23, no. 1, pp. 22-27, 2005.

[120] R. Wirawan, E. S. Zainudin, and S. M. Sapuan, "Mechanical properties of natural fibre reinforced PVC composites: a review," Sains Malaysiana, vol. 38, no. 4, pp. 531-535, 2009.

[121] N. Chand, R. K. Tiwary, and P. K. Rohatgi, "Bibliography Resource structure properties of natural cellulosic fibres-an annotated bibliography," Journal of Materials Science, vol. 23, no. 2, pp. 381-387, 1988.

[122] A. K. Datta, B. K. Samantaray, and S. Bhattacherjee, "Mechanical and dielectric properties of pineapple fibres," Journal of Materials Science Letters, vol. 3, no. 8, pp. 667-670, 1984.
[123] N. M. Stark and L. M. Matuana, "Surface chemistry changes of weathered HDPE/wood-flour composites studied by XPS and FTIR spectroscopy," Polymer Degradation and Stability, vol. 86, no. 1, pp. 1-9, 2004.

[124] M. Jonoobi, J. Harun, P. M. Tahir, L. H. Zaini, S. SaifulAzry, and M. D. Makinejad, "Characteristics of nanofibers extracted from kenaf core," BioResources, vol. 5, no. 4, pp. 2556-2566, 2010.

[125] F. R. Jones, "Moisture absorption anomalous effects," in Handbook of Polymer Fibre Composites, pp. 371-375, Longman Scientific and Technical Group, London, UK, 1994.

[126] N. Lopattananon, Y. Payae, and M. Seadan, Influence of Fiber Modification on Interfacial Adhesion and Mechanical Properties of Pineapple Leaf Fiber-Epoxy Composites, Wiley-Interscience, 2008.

[127] J. C. T. B. Bhattacharyya and A. K. Biswas, "Short pineapple leaf fibre reinforced rubber composites," Plastics and Rubber Processing and Applications, vol. 6, pp. 119-125, 1986.

[128] B. Ellis, M. S. Foundz, and J. R. Bell, "Effect of cure on the impact behaviour of an epoxy resin," ECF 12-Fracture from Defects, 1993.

[129] J. Gassan and A. K. Bledzki, "Possibilities for improving the mechanical properties of jute/epoxy composites by alkali treatment of fibres," Composites Science and Technology, vol. 59, no. 9, pp. 1303-1309, 1999.

[130] D. G. Hepworth, D. M. Bruce, J. F. V. Vincent, and G. Jeronimidis, "Manufacture and mechanical testing of thermosetting natural fibre composites," Journal of Materials Science, vol. 35, no. 2, pp. 293-298, 2000.

[131] M. Z. Rong, M. Q. Zhang, Y. Liu, G. C. Yang, and H. M. Zeng, "The effect of fiber treatment on the mechanical properties of unidirectional sisal-reinforced epoxy composites," Composites Science and Technology, vol. 61, no. 10, pp. 1437-1447, 2001.

[132] I. van de Weyenberg, T. Chi Truong, B. Vangrimde, and I. Verpoest, "Improving the properties of UD flax fibre reinforced composites by applying an alkaline fibre treatment," Composites Part A: Applied Science and Manufacturing, vol. 37, no. 9, pp. 1368-1376, 2006.

[133] F. G. Shin, X.-J. Xian, W.-P. Zheng, and M. W. Yipp, “Analyses of the mechanical properties and microstructure of bambooepoxy composites," Journal of Materials Science, vol. 24, no. 10, pp. 3483-3490, 1989.

[134] E. T. N. Bisanda, "Effect of alkali treatment on the adhesion characteristics of sisal fibres," Applied Composite Materials, vol. 7, no. 5-6, pp. 331-339, 2000.

[135] A. K. Mohanty, P. C. Tripathy, M. Misra, S. Parija, and S. Sahoo, "Chemical modification of pineapple leaf fiber: graft copolymerization of acrylonitrile onto defatted pineapple leaf fibers," Journal of Applied Polymer Science, vol. 77, no. 14, pp. 3035-3043, 2000.

[136] J. George, M. S. Sreekala, S. Thomas, S. S. Bhagawan, and N. R. Neelakantan, "Stress relaxation behavior of short pineapple fiber reinforced polyethylene composites," Journal of Reinforced Plastics and Composites, vol. 17, no. 7, pp. 651-672, 1998.

[137] P. K. Mallick, Fiber-Reinforced Composites: Materials, Manufacturing, and Design, CRC Press, New York, NY, USA, 2008.

[138] H. Li, Synthesis, characterization and properties of vinyl ester matrix resins [Ph.D. thesis], Virginia University, Blacksburg, Va, USA, 1998.

[139] R. Joffe, J. Andersons, and L. Wallström, "Strength and adhesion characteristics of elementary flax fibres with different surface treatments," Composites Part A: Applied Science and Manufacturing, vol. 34, no. 7, pp. 603-612, 2003. 
[140] P. S. Mukherjee and K. G. Satyanarayana, "Structure and properties of some vegetable fibres-part 2: pineapple fibre (Ananas comosus)," Journal of Materials Science, vol. 21, no. 1, pp. 51-56, 1986.

[141] M. A. Dweib, B. Hu, A. O’Donnell, H. W. Shenton, and R. P. Wool, "All natural composite sandwich beams for structural applications," Composite Structures, vol. 63, no. 2, pp. 147-157, 2004.

[142] D. Ray, B. K. Sarkar, S. Das, and A. K. Rana, "Dynamic mechanical and thermal analysis of vinylester-resin-matrix composites reinforced with untreated and alkali-treated jute fibres," Composites Science and Technology, vol. 62, no. 7-8, pp. 911-917, 2002.

[143] P. J. Herrera-Franco and A. Valadez-González, "Mechanical properties of continuous natural fibre-reinforced polymer composites," Composites Part A: Applied Science and Manufacturing, vol. 35, no. 3, pp. 339-345, 2004.

[144] M. N. Ichazo, C. Albano, J. González, R. Perera, and M. V. Candal, "Polypropylene/wood flour composites: treatments and properties," Composite Structures, vol. 54, no. 2-3, pp. 207-214, 2001.

[145] W. Jiang and S. C. Tjong, "Thermal stability of polycarbonate composites reinforced with potassium titanate whiskers: effect of coupling agent addition," Polymer Degradation and Stability, vol. 66, no. 2, pp. 241-246, 1999.

[146] R. Mangal, N. S. Saxena, M. S. Sreekala, S. Thomas, and K. Singh, "Thermal properties of pineapple leaf fiber reinforced composites," Materials Science and Engineering A, vol. 339, no. 1-2, pp. 281-285, 2003.

[147] M. Idicula, S. K. Malhotra, K. Joseph, and S. Thomas, "Dynamic mechanical analysis of randomly oriented intimately mixed short banana/sisal hybrid fibre reinforced polyester composites," Composites Science and Technology, vol. 65, no. 7-8, pp. 1077-1087, 2005.

[148] K. L. Fung, X. S. Xing, R. K. Y. Li, S. C. Tjong, and Y.-W. Mai, "An investigation on the processing of sisal fibre reinforced polypropylene composites," Composites Science and Technology, vol. 63, no. 9, pp. 1255-1258, 2003.

[149] K. S. Ahmed and S. Vijayarangan, "Elastic property evaluation of jute-glass fibre hybrid composite using experimental and CLT approach," Indian Journal of Engineering and Materials Sciences, vol. 13, no. 5, pp. 435-442, 2006.

[150] S. Panthapulakkal and M. Sain, "Studies on the water absorption properties of short hemp-glass fiber hybrid polypropylene composites," Journal of Composite Materials, vol. 41, no. 15, pp. 1871-1883, 2007.

[151] M. S. Sreekala, S. Thomas, and G. Groeninckx, "Dynamic mechanical properties of oil palm fiber/phenol formaldehyde and oil palm fiber/glass hybrid phenol formaldehyde composites," Polymer Composites, vol. 26, no. 3, pp. 388-400, 2005.

[152] L. A. Pothan, P. Potschke, R. Habler, and S. Thomas, "The static and dynamic mechanical properties of banana and glass fiber woven fabric-reinforced polyester composite," Journal of Composite Materials, vol. 39, no. 11, pp. 1007-1025, 2005.

[153] M. Idicula, N. R. Neelakantan, Z. Oommen, K. Joseph, and S. Thomas, "A study of the mechanical properties of randomly oriented short banana and sisal hybrid fiber reinforced polyester composites," Journal of Applied Polymer Science, vol. 96, no. 5, pp. 1699-1709, 2005.

[154] H. Anuar, S. H. Ahmad, R. Rasid, A. Ahmad, and W. N. Wan Busu, "Mechanical properties and dynamic mechanical analysis of thermoplastic-natural-rubber-reinforced short carbon fiber and kenaf fiber hybrid composites," Journal of Applied Polymer Science, vol. 107, no. 6, pp. 4043-4052, 2008.

[155] K.-Y. Chiang, K.-L. Chien, and C.-H. Lu, "Hydrogen energy production from disposable chopsticks by a low temperature catalytic gasification," International Journal of Hydrogen Energy, vol. 37, no. 20, pp. 15672-15680, 2012.

[156] Z.-S. Hung, C.-C. Chang, C.-F. H. Chang et al., "Autoclaving treatment of wasted disposable bamboo chopsticks," Journal of the Taiwan Institute of Chemical Engineers, vol. 44, no. 6, pp. 1010-1015, 2013.

[157] P. R. K. A. Basu and K. P. Chellamani, "Jute and pineapple leaf fibres for the manufacture of technical textiles," Asian Textile Journal, vol. 12, pp. 94-96, 2003.

[158] A. Anon, "A guide to unusual natural fibres: pineapple leaf fibre (PALF)," Textiles, vol. 21, no. 3, 1992.

[159] Y. Yusof, M. R. Ahmad, M. S. Wahab, M. S. Mustapa, and M. S. Tahar, "Producing paper using pineapple leaf fiber," Advanced Materials Research, vol. 383-390, pp. 3382-3386, 2012.

[160] V. G. Geethamma, K. T. Mathew, R. Lakshminarayanan, and S. Thomas, "Composite of short coir fibres and natural rubber: effect of chemical modification, loading and orientation of fibre," Polymer, vol. 39, no. 6-7, pp. 1483-1491, 1998.

[161] J. A. Youngquist, A. M. Krzysik, B. W. English, H. N. Spelter, and P. Chow, "Agricultural fibers for use in building components," in Proceedings of the Conference on the Use of Recycled Wood and Paper in Building Applications, pp. 123-134, September 1996.

[162] B. Jayanta, "Plastics filled with agrowastes," Popular Plastics and Packaging, vol. 48, no. 11, pp. 63-74, 2003. 

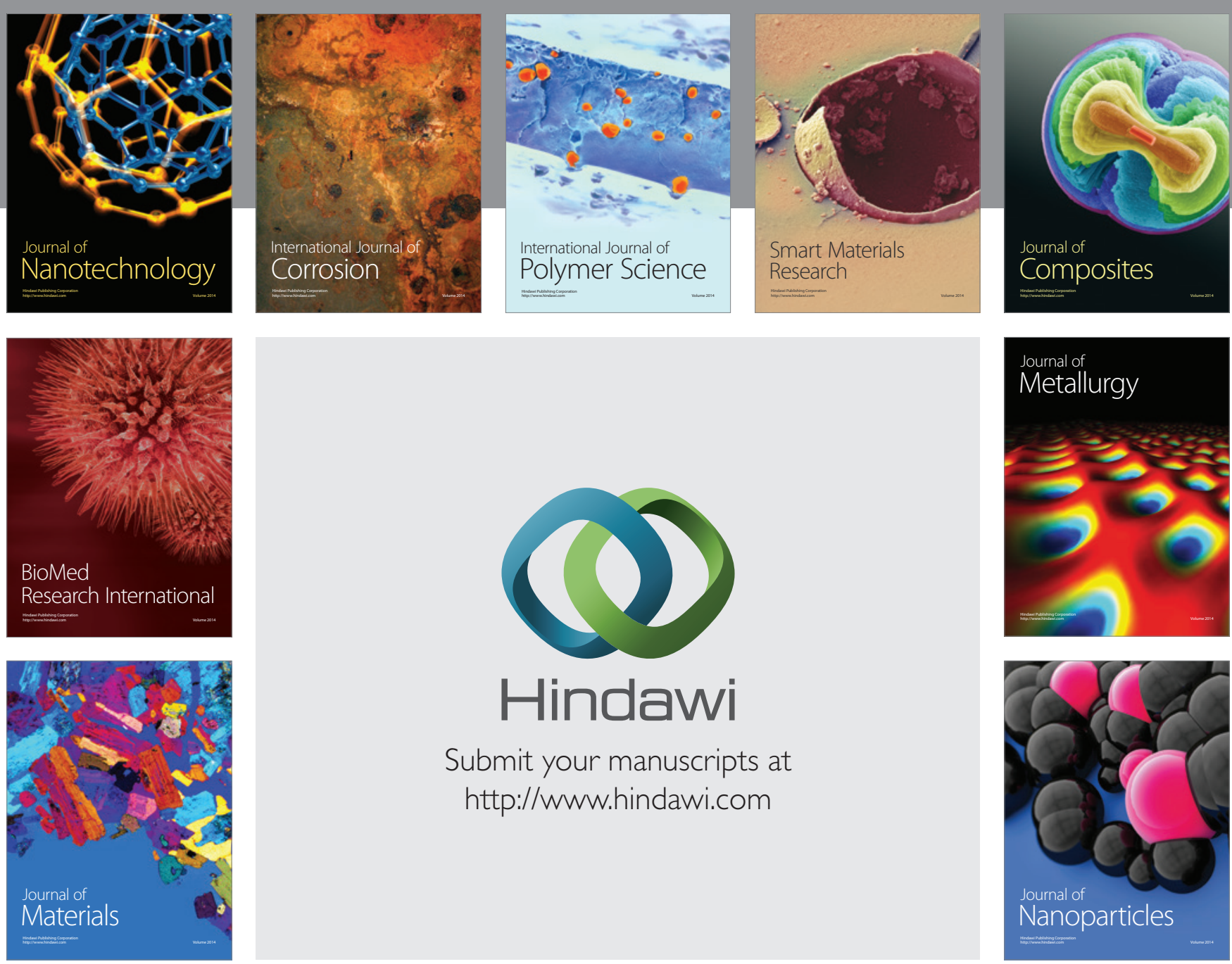

Submit your manuscripts at http://www.hindawi.com
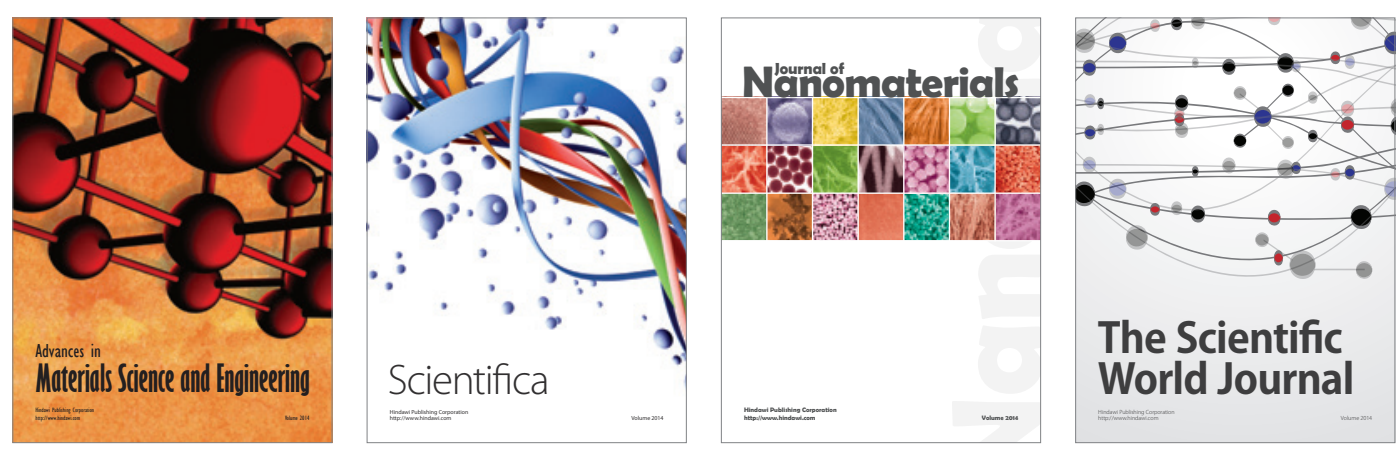

\section{The Scientific World Journal}
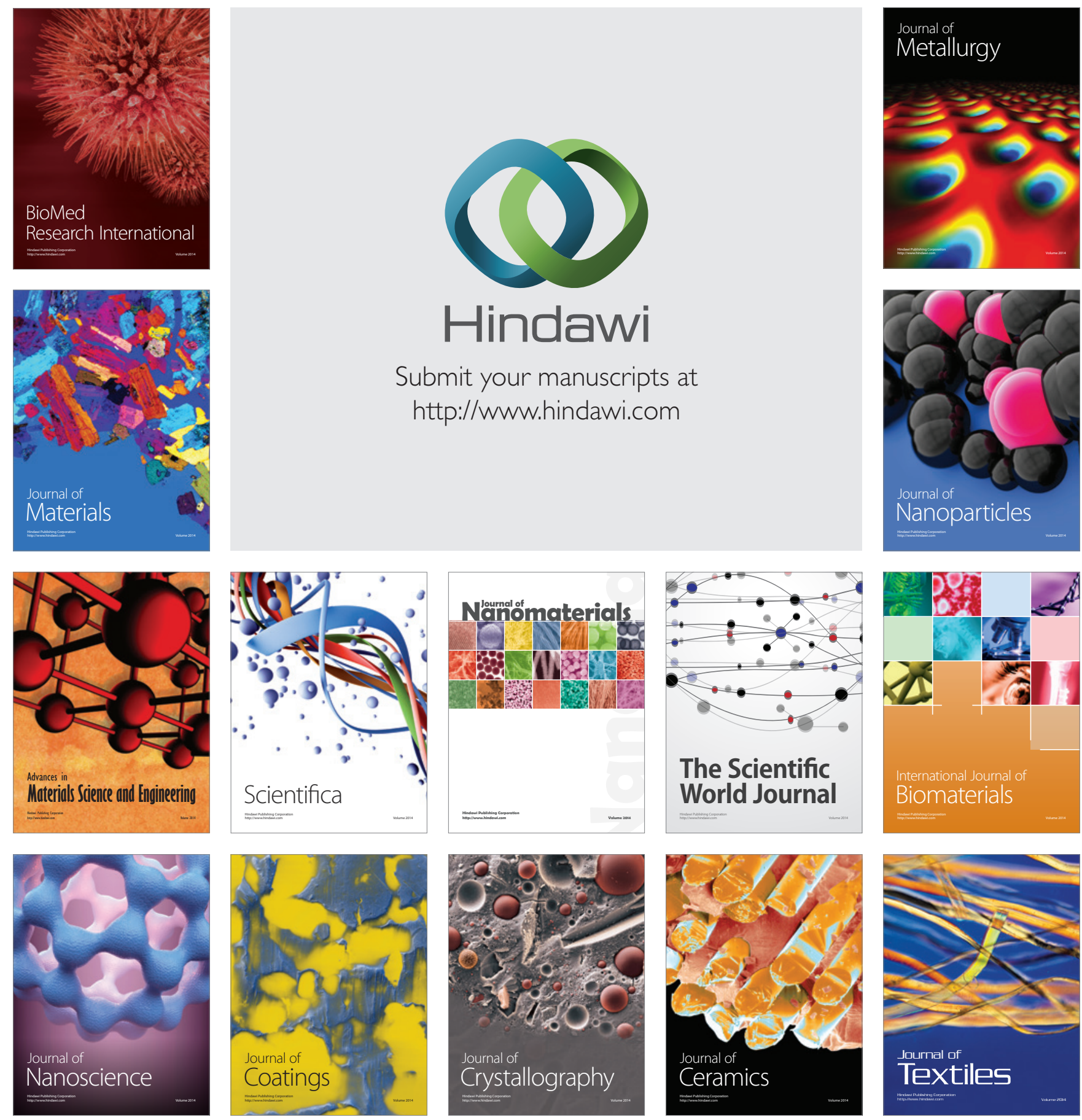